\title{
Modstandsbevægelsen i Åbenrå og omegn
}

\author{
Af Aage Trommer.
}

\begin{abstract}
Efterfølgende korte skildring af modstandsbevægelsen i Åbenrå skal kun betragtes som et oversigtsmassigt forarbejde til en større fremstilling af det illegale arbejde i Region III's område. Af denne grund vil yderligere undersøgelser muligvis revidere visse af de synspunkter, jeg her fremsætter. Jeg har dog tillid til, at sådanne revisioner kun vil vedrøre detailpunkter. Den, der har forstehånds kendskab til de skildrede begivenheder, vil let kunne se, hvor kildegrundlaget har været ufuldkomment, og hvor fremdragelsen af nyt materiale derfor er onskelig. Kan denne skildring bidrage hertil, vil jeg hilse det meget velkommen.
\end{abstract}

\section{INDLEDENDE BEMARKNINGER}

For så vidt er det principielt en umulig opgave at give en beskrivelse af en enkelt bys eller et enkelt amts illegale historie, som om den var en isoleret enhed. Man skaber herved en kunstig opdeling, som samtiden ikke kendte. Det var karakteristisk for besættelsestidens illegale arbejde, da det kom i gang, at der fra by til by og fra landsdel til landsdel skabtes et finmasket net af forbindelser. Kontakter mellem ligesindede kredse blev etableret og udviklede sig hurtigt til veritable illegale organisationer, der kunne omfatte en hel landsdel, og disse blev med forbavsende hast atter koblet ind på landsomfattende organisationsdannelser. Ofte blev initiativet til illegalt arbejde taget ovenfra, således at en illegal organisation, der stræbte efter at blive landsomfattende, bevidst søgte kontakter på det lokale plan. Man kunne umiddelbart mene, at isolationen måtte være et naturligt ledsagefænomen til en virksomhed, man i sagens natur ikke kunne tale højt om. Men overalt, hvor mennesker gik ind $i$ det illegale arbejde, overvandt de med stor hurtighed alle tendenser til isolation. Intet afgrænset, lokalt område levede sit eget illegale liv uden forbindelse med andre områder. Disse bemærkninger har fuld 


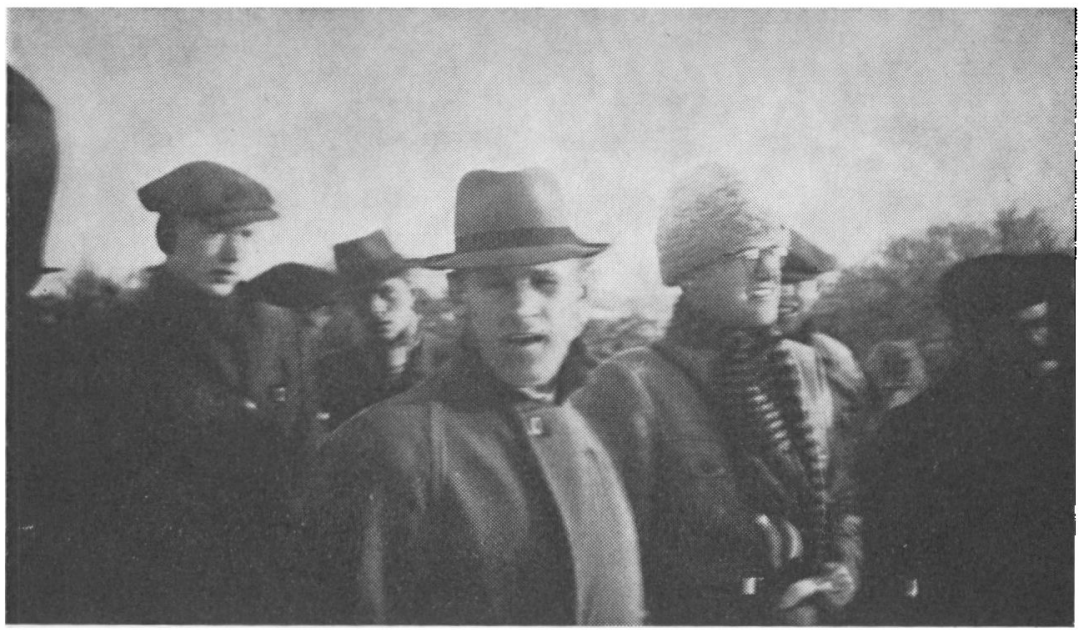

I dagene den 3.-5. junuar 1941 afholdtes pả Ronshoved Hojskole et sonderjysk terransportskursus, hvor bl. a. dr. Vilhelm la Cour, forstander Aage Moller og pastor Harald Sandbak talte - alle navne, der på dette tidspunkt var tilknytket Dansk Samling. På billedet ses ( $i$ midten) kaptajn $K$. Kjeldsen, da terransportsleder $i$ Gråsten, senere terrensportsinstruktor $i$ Jylland og Fyn, $i$ 1944 placeret $i$ den forste nordslesvigske regionsledelse. Endv. hojskoleforstander Robert Stcermose, Stovring, (med pelshue), medlem af Dansk Samling og illegalt aktiv allerede $i$ 1942, og mobelsnedker Jes Peter Asmussen, Hellevad (1919-44) - med kasket, af Abenrä-kredsen aktiviseret i terransportsbevagelsen og senere $i$ ventegruppedannelsen, arresteret $i$ juni 1944, dod $i$ koncentrationslejren $i$ Neuengamme den 17, december 1944.

gyldighed også for Ảbenrå, og i overensstemmelse hermed må udviklingen af det illegale arbejde i Åbenrå til stadighed ses $i$ relation til de større enheder, hvoraf det kun var en del.

Overalt i Danmark blev det illegale arbejdes spæde begyndelse gjort af mennesker, der ikke alene stod som fjender af tyskerne, men også som skarpe kritikere af de politikere, der havde affundet sig med de tyske ultimative krav den 9. april 1940, og som siden da var gledet ind i samarbejdspolitikkens kloge, men eftergivende kurs. For dem, der fandt denne politik en vederstyggelighed, måtte en fjernelse af den regering, der indlod sig på at føre den, og af den Rigsdag, der godkendte den, være det første skridt på vejen frem mod andre tilstande. Det alternativ, der blev opstillet, var en bruddets politik $\mathbf{i}$ forholdet til tyskerne. Der onskedes snorske tilstande*. Sted efter sted var det folk med dette politiske syn, der blev det illegale arbejdes 


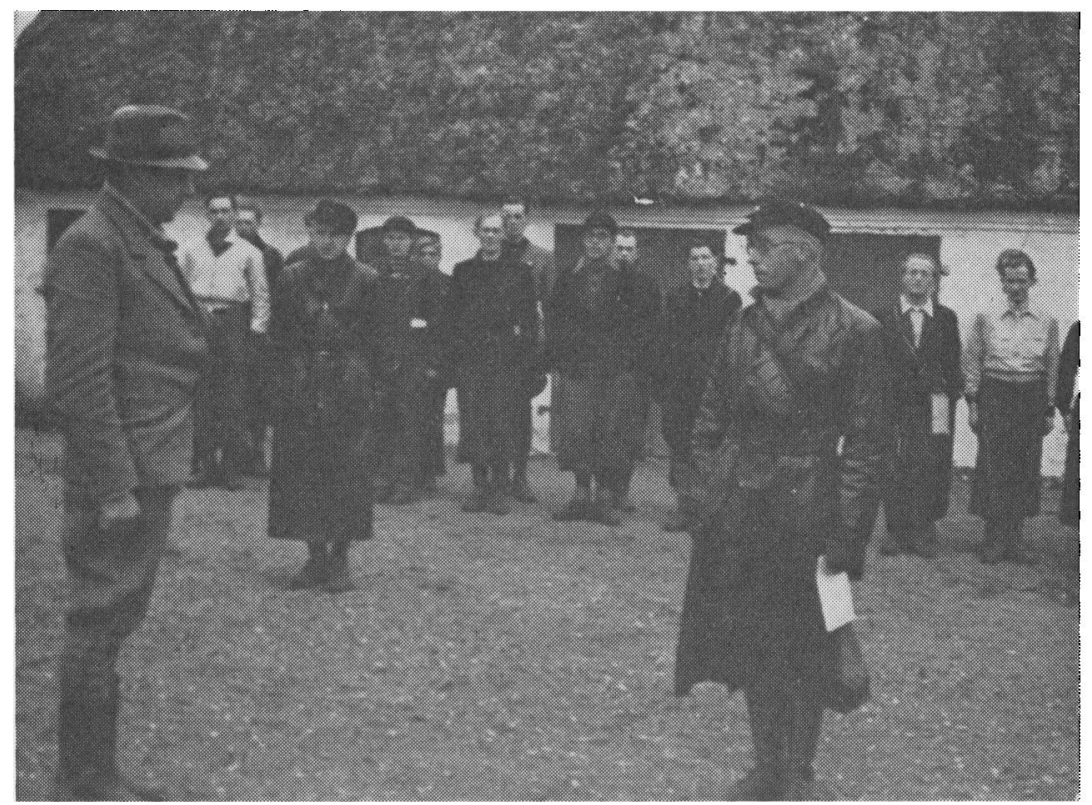

En del af Abenrå terransportsstyrke. Chefen, lojtnant Poulsen afleverer styrken til gårdejer Karl Hansen, Dybvighoved, hvor ovelsen fandt sted. Gården blev $i 1944$ brugt som depot for ammunition og sprangstof.

pionerer - det være sig kommunister, tilhængere af partiet Dansk Samling eller folk fra et af de samarbejdende partier, der blot havde måttet sige fra over for deres parti i denne nye, højst egenartede situation. I overensstemmelse hermed rekrutteredes de kredse, der således indlod sig på at føre "privat udenrigspolitik «, i høj grad blandt folk, der hidtil havde befundet sig på det politiske livs overdrev eller helt havde stået uden for politik. Det var for en stor del nye, ukendte mænd, der rykkede ud af anonymiteten.

Ikke mindst for Nordslesvig gælder det, at lederne af det traditionelle nationale arbejde og de, der bar det illegale arbejde, levede $i$ to helt forskellige verdener uden nogen indbyrdes kontakt. Det illegale arbejde i denne landsdel blev udført af mennesker, der ikke sad placeret i det gamle nationale apparat, og som for en stor del slet ikke var sønderjyder, men tilflyttede »kongerigske «. ${ }^{1}$ Denne alment nordslesvigske iagttagelse gælder også 
for Åbenrå - måske i særlig grad for Åbenrå. Der var fra første færd kold luft mellem Brøndlund slot og de aktivister, der ville vælte samarbejdets politik, ${ }^{2}$ og den kølige atmosfære bevaredes til besættelsens sidste dage og ud over befrielsen.

\section{2. ÅBENRẢ-KREDSEN}

I Åbenrå udgik pionererne $i$ det illegale arbejde fra den såkaldte "Åbenrå-kreds «. På initiativ af handelsmedhjælper Hans Mørup og med ham som leder havde helt tilbage fra den 15. august 1940 en kreds på 12-15 mand med regelmæssige mellemrum holdt møder.' Deres formål var at drøfte den situation, Danmark var kommet ud $i$, og at søge udveje for den genrejsning af landet, som de fandt nødvendig. De nåede hurtigt frem til den opfattelse, at et af midlerne dertil var en fysisk uddannelse af den ungdom, der ikke havde mulighed for at få en militær uddannelse, og med stor flid og ihærdighed tog de ikke blot initiativet til oprettelsen af en terrænsportsafdeling i Ảbenrå, men deltog også personligt i denne afdelings arbejde som delingsog gruppeførere. ${ }^{4}$ Det, der foresvævede Åbenrå-kredsen, var, at dens terrænsportsafdeling sammen med de andre afdelinger, der skød frem $i$ den ene by efter den anden, kunne blive en dansk udgave af det svenske sskyddskår «, datidens form for hjemmeværn.

Terrænsportsarbejdet begyndte allerede $\mathrm{i}$ september 1940, og kort efter kom kredsen også ind $i$ et frugtbart arbejde med at påvirke den offentlige opinion $i$ aktivistisk retning. Omkring årsskiftet 1940-41 fik den nemlig forbindelse med dr. phil. Vilhelm la Cour, der talte såvel tyskerne som samarbejdspolitikken midt imod dels i en række foredrag, dels $i$ artikler og pjecer, der til dels byggede på foredragene. ${ }^{\S}$ De skriftlige publikationer var af et sådant indhold, at man måtte regne med, at myndighederne på tyskernes krav ville beslaglægge dem, så såre de var udkommet. Det gjaldt derfor om at få dem spredt så hurtigt som overhovedet muligt ved hjælp af bestillinger, der var modtaget på forhånd, og dette arbejde deltog kredsen i med stor flid.

Forbindelsen med la Cour var etableret via partiet Dansk Samling, idet kredsen blandt sine medlemmer talte aktive medlemmer heraf. Kredsen gav Dansk Samling sin fulde støtte. Den 
arbejdede for udbredelsen af dets publikationer, herunder især tidsskriftet $\gg$ Det tredje Standpunkt «, og ved folketingsvalget $i$ marts 1943 gik den aktivt ind for partiets synspunkter. To af kredsens medlemmer var kandidater for partiet, resten optrådte som stillere, og kredsen bekostede partiets sønderjyske valgpropaganda.

Ingen af disse arbejdsgrene - hverken terrænsportsarbejdet eller samarbejdet med la Cour og Dansk Samling - gjorde kredsen illegal, men de dannede tilsammen en række forudsætninger, der fik betydning, da den gik ind $i$ et egentligt underjordisk arbejde. I sine terrænsportsmedlemmer fik den et rekrutteringsmateriale til brug den dag, da der skulle dannes illegale grupper, og $i$ sin øvrige virksomhed havde den skabt en række forbindelser til ligesindede såvel i Ảbenrå med opland som i andre byer og egne rundt om $i$ landet.

På grænseområdet mellem legal og illegal virksomhed lå den tilknytning, kredsen i 1942 fik til den såkaldte P-ordning. Den var en af hæren skabt plan til gennemførelse af en landsomfattende interimistisk mobilisering af hjemsendte værnepligtige $i$ en kritisk situation, hvor normale forholdsregler ikke lod sig gennemføre. Denne ordning administreredes i Ảbenrå som andetsteds af politiet, og der blev mellem dette og kredsen skabt en uformel aftale om, at kredsen i givet fald skulle stille sine terrænsportsgrupper til rådighed for P-planen. Planen var illegal for så vidt, som den søgtes holdt hemmelig for tyskerne, men man var i tilfælde af, at disse fik kendskab til den, rede til at etablere det alibi for den, at den var tænkt som et middel til at fremskaffe et hjælpepoliti $i$ en katastrofesituation.

Den første egentligt illegale opgave, kredsen blev stillet over for, kom bogstaveligt talt dumpende ind ad døren til den. Den 6. april 1942 bankede nordmanden Peter Jebsen på hos et af kredsens medlemmer, pastor Sigfred Riishøjgaard, Rise. Peter Jebsen var en norsk student, der oprindelig var gået over grænsen fra Norge til Sverige for derfra at komme videre til England og dér blive aktiv krigsdeltager. Under forsøget var han blevet fanget af tyskerne, men under transport fra Norge til en fangelejr i Tyskland sprang han i Nordslesvig af toget og endte helt tilfældigt hos præsten i Rise. Riishøjgaard tog ham med til 
kredsens næste møde - mødedatoen rummede sin egen symbolik, det var den 9. april 1942. Dermed befandt kredsen sig midt $i$ en konkret illegal opgave. Peter Jebsen skulle hjælpes med husly og livsfornødenheder, og der skulle skaffes en flugtvej til ham, idet han stadigt var fast opsat på at komme til England. Efter et par måneders ophold i Nordslesvig, hvorfra hans slægt for øvrigt stammede, blev han sendt til København til forbindelser, kredsen havde skaffet, og derfra gik hans vej efter store forsinkelser videre til Sverige i foråret 1943.

Peter Jebsen blev blot den første i en række af flygtninge, som kredsen hjalp bort. En franskmand, der var flygtet fra en tysk fangelejr, dukkede pludseligt op og måtte hjælpes. Et par sønderjyder, der ikke havde deres indfødsret $\mathbf{i}$ orden og derfor var blevet indkaldt til tysk militærtjeneste, blev hjulpet af vejen. Senere blev folk, der var eftersøgt for illegalt arbejde, skaffet bort. Een af disse kom fra Esbjerg, et par fra Sønderborg. Kredsen fik etableret en veritabel flugtrute, der gik under kodenavnet $\$$ s $\mathrm{c}$.

I efteråret 1943 gik kredsen ind $i$ arbejdet med illegale blade. Dansk Samlings leder, Arne Sørensen, gik efter den 29. august 1943 under jorden og skrev en række illegale henvendelser, -Niels Jydes Breve", hvori han bl. a. talte sabotagens sag og opfordrede til dannelsen af seksmandsgrupper. Kredsen mangfoldiggjorde og distribuerede disse "breve*, som så mange andre gjorde det, og der er ingen tvivl om, at de synspunkter, Arne Sørensen gjorde sig til talsmand for, også har ovet deres påvirkning på kredsens medlemmer.

\section{DET BOECK'SKE INITIATIV}

Det blev dog ikke kredsen, der var først på pletten til at konkretisere tanken om sabotage. Eren herfor tilkommer overretssagfører Holger Boeck. Denne havde helt tilbage fra 1921, da han kom nordfra og nedsatte sig som sagfører i Ảbenrå, været en af byens fremtrædende danske skikkelser. Det var Boeck til stor fortrydelse, at der ikke i Nordslesvig havde fundet nævneværdig sabotage sted. Det forekom ham, at den grænse ved Kongeåen, som man ellers på alle andre områder havde gjort sit bedste for at udslette, $\mathbf{i}$ den henseende var ved at genopstå. I det ovrige 
Danmark begyndte en organiseret sabotage i 1942, ledet og udført af kommunister og gennemført med primitive, hjemmelavede spræng- og brandbomber, indtil engelsk stof blev tilfort fra februar 1943 og fremefter. Denne aktivitet var imidlertid ikke kommet Nordslesvig nærmere end Esbjerg og Kolding.

Hvad der før Boecks initiativ var sket af sabotager og sabotagelignende handlinger i Åbenrå med opland, fremgår af følgende korte oversigt over sager, der fremsendtes til Statsadvokaturen for særlige anliggender:

Marts 1941. Blymuffer fra tyske kabelruller fjernet. Gerningen vurderet som almindeligt metaltyveri eller børnestreger.

20. november 1941. En rude slået ind i Ortskommandanturens bygning, Ảbenrå.

September 1942. Et geværprojektil stoppet ind $\mathrm{i}$ dorlåsen til tysk militært kontor i Åbenrå. Gerningen vurderet som børnestreger.

13. november 1942. "Maling el. l. h hældt $i$ olien på tysk militær personbil i Ảbenrå. Motoren led ingen skade.

11. marts 1943. 17 russiske bilhjul søgt stjålet fra tysk jernbanevogn i Rødekro.

26. marts 1943. Ildløs i bræddestabel på havnen i Ảbenrå. Vurderet som pyromanbrand.

7. juli 1943. Sabotage mod en værnemagten tilharende telefonledning. Vurderet som uforsætlig skade tilføjet af Højspændingsværkets kulkran.

26. juli 1943. Fire trykluftledninger på tysk godsvogn overskåret på Bolderslev station.

28. juli 1943. Kasse med' sprængstof forsvundet under forsendelse fra Flensborg til Åbenrå.

9. august 1943. Carborundum anbragt $i$ krumtaphuset på lastbil, der korte for tyskerne.

Dertil kommer en række tilfælde af tyverier af reservehjul og automobildæk fra tyske vogne, hvor man tør formode, at sortbørsmotivet har været det primære. Det samme gælder muligvis sagen den 11. marts 1943. Selv bortset herfra skal man helt frem til juli 1943, før de anmeldte sager hæver sig over det helt ubetydelige og ligegyldige.

Boeck blev ca. marts/april 1943 kontaktet angående distribuering af illegale blade af journalist Kate Fleron, der på dette tidspunkt foretog en som foredragsturné camoufleret rejse for at opdyrke illegale kontakter. Kort tid efter forelagde Boeck for hende sin idé om en sabotage mod Abenrå Motorfabrik, der 
arbejdede for den tyske værnemagt. Via sin tilknytning til Frit Danmark kunne Kate Fleron lade tanken gå videre til den på denne tid meget aktive kommunistiske sabotageorganisation i Esbjerg, og lederen af denne, malersvend Hans Peder Poulsen fra Odense, var da også i Åbenrå $i$ august 1943 for at sondere terrænet. Han havde dog under besøget sin interesse $\mathrm{i}$ højere grad henvendt på Højspændingsværket. Planerne om sabotage $\mathbf{i}$ Abenrå nåede imidlertid ikke i denne omgang at blive til noget, da Esbjerg-organisationen i slutningen af august blev revet op af tyskerne. Men Boeck arbejdede videre med sin kongstanke. Derimod var det denne Eshjerg-organisation, der gennem en lokalgruppe stod bag den mislykkede aktion mod DSB's oliedepot i Tønder den 16. april $1943 \mathrm{og}$ bag den vellykkede aktion mod lokomotivremisen i Tønder den 1. juni 1943. Den har altså æren for den første egentlige sabotage i Nordslesvig.

\section{KREDSENS INDDRAGELSE I SABOTAGE}

På det tidspunkt, da Esbjergs sabotageleder var på rekognoscering i Abenrå, var imidlertid en borgerlig, ikke-kommunistisk sabotageorganisation under dannelse $i$ Nordslesvig. I Tønder dannede en lille kreds af mænd omkring ingeniør J. M. Bøge en sabotagegruppe $^{7}$ og skaffede sig $i$ andre byer kontakter, således i Sønderborg, Padborg og Tinglev. I Ảbenrå henvendte Bøge sig til farver J. F. Jacobsen, hvem han kendte fra Dansk Samling, og da denne accepterede opfordringen, blev Åbenrå-kredsen, hvoraf Jacobsen var et fremtrædende medlem, således koblet på dette initiativ til sabotage.

Da Bøge havde fået sin lokale organisation stablet på benene, søgte han forbindelse opad og opnåede kontakt med den engelske faldskærmsorganisation (SOE), der havde en mand siddende $i$ Esbjerg - fra ca. 1. august 1943 løjtnant Aage Moller Christensen. Forbindelsen med Møller Christensen betød, at man fik adgang til engelsk sprængstof. Tønder-gruppens første sprængning - dens generalprøve så at sige - fandt sted den 28 . august 1943, da den sprængte en transformator i nærheden af Vilsbæk.

I løbet af efteråret 1943 gennemførte Bøges organisation derpå en række sabotager, der er karakteristiske ved hovedsagelig at være samlet $i$ serier. Natten til kongens fødselsdag den 26. sep- 
tember 1943 sprængtes jernbanenettet en række forskellige steder i Nordslesvig, hvilket skete i koordination med tilsvarende sprængninger i Nørrejylland. Natten til den 15. oktober sprængtes 9 transformatortårne, og natten til den 29. november sprængtes banenettet på ikke færre end 54 forskellige steder fra Brøns på banen Tønder-Ribe over tværbanen Tonder-Tinglev til Hjordkær på banen fra Padborg nordpå. I disse sprængninger var Ảbenrå-kredsen repræsenteret natten til den 15. oktober, da den sprængte transformatorerne i Nørby og Stollig nord for Abenrå, ligesom en sabotage med brandbomber mod et tysk billager $i$ Voetmanns tømmerhal på Åbenrå havn den 4. november 1943 må tilskrives den. Virkningen af den sidste sabotage blev dog meget beskeden. Derimod er en aktion mod fabriken DAPA den 29. december 1943 udført "free lance af en student, der tilhørte den københavnske sabotageorganisation BOPA, mens han var hjemme på juleferie."

Kort efter dens sidste store indsats fik Bøges organisation en brat ende. Som folge af arrestationer i Kolding og Fredericia blev den $i$ begyndelsen af december 1943 revet op. Bøge selv måtte flygte til Sverige, og med ham forsvandt også kontakten opefter. De etablerede undergrupper, deriblandt også Ảbenråkredsen, hang i luften med stærkt svækkede illegale kontakter.

\section{NYE MALS ETNINGER I DET ILLEGALE ARBEJDE}

Åbenrå-kredsen fik dog ikke lov til at sidde $\mathrm{i}$ illegal uvirksomhed ret længe. Kort efter nytår 1944 blev farver Jacobsen opsøgt af godsejer Flemming Juncker, der på dette tidspunkt berejste Jylland for at danne regionsledelser. Nogle bemærkninger om baggrunden for dette arbejde vil være nødvendige for skildringen af de følgende begivenheder.

Som nævnt rummede den tidlige illegale bevægelses kamp også et klart indenrigspolitisk aspekt, nemlig kampen mod samarbejdspolitikken. Denne kamp blev ført dels ved hjælp af illegale blade og sabotage, dels med et nyt våben, der kom til pludselig anvendelse $i$ august $1943 \mathrm{og}$ fik en uventet og overraskende succes: Folkestrejken. I by efter by landet over udbrød der strejker, der ikke blot omfattede arbejderklassen, men også forretningsfolk og funktionærer $i$ offentlige og private virksomheder. 


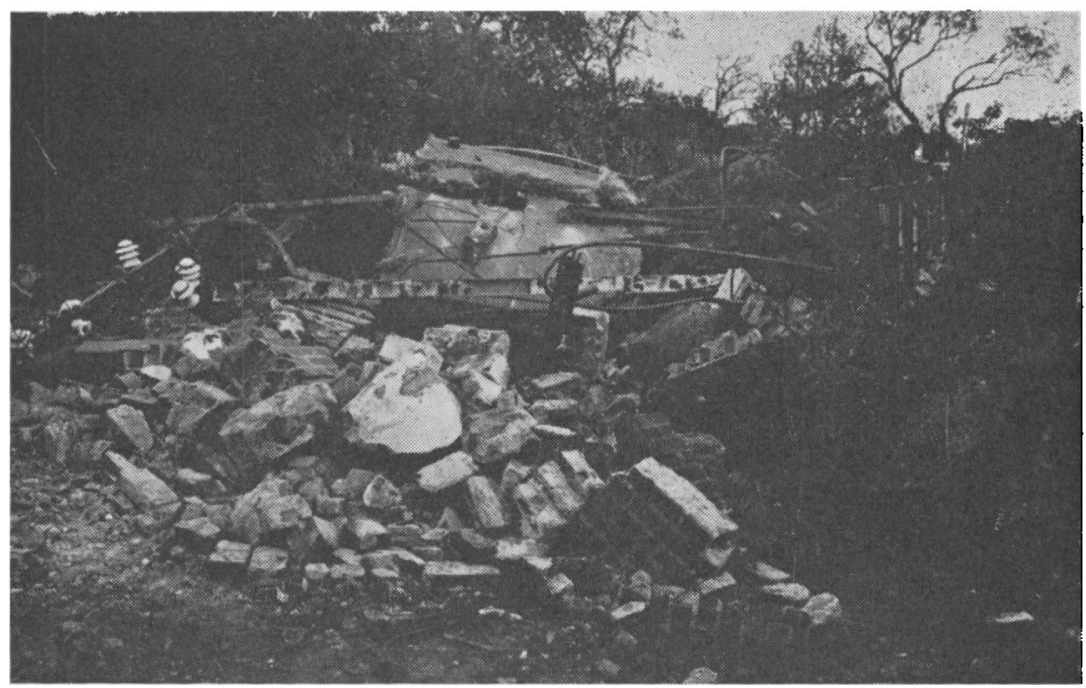

Resultatet af sabotagen mod transformatortårnet i Stollig natten til den 15. okt. 1943.

Strejkebevægelsen begyndte i Esbjerg, brød derefter ud i samtlige fynske byer med Odense $i$ spidsen og bredte sig videre til en række jyske - især nordjyske - byer og nogle sjællandske. Den virksomste faktor i denne bevægelse var kommunisterne, uden hvis dygtige arbejde strejkerne ikke ville være blevet etableret, endsige gennemført i det omfang, der faktisk blev tilfældet.' Hele denne bolge af strejker gik imidlertid uden om Sønderjylland. Ikke et eneste sted i denne landsdel kom det til rore eller uroligheder, der hævede sig op over nogle rudeknusninger og sammenstimlinger på gaderne. Denne konstatering gælder også for Ảbenrå, hvor alt, hvad der hændte af ekstraordinært i de kritiske dage, var følgende:

20. august 1943. Brand i godsvogn, der var læsset med hø, på Abenrå havn.

27. august 1943. Årstallet $\approx 1918$ « malet på forretningsvinduer, tilhørende medlemmer af det tyske mindretal.

Natten til den 29. august 1943. Hærværk mod det tyske konsulats højhedsskilt.

Resultatet af begivenhederne $i$ august 1943 blev regeringens tilbagetræden og samarbejdspolitikkens ophør den 29. august 1943. 


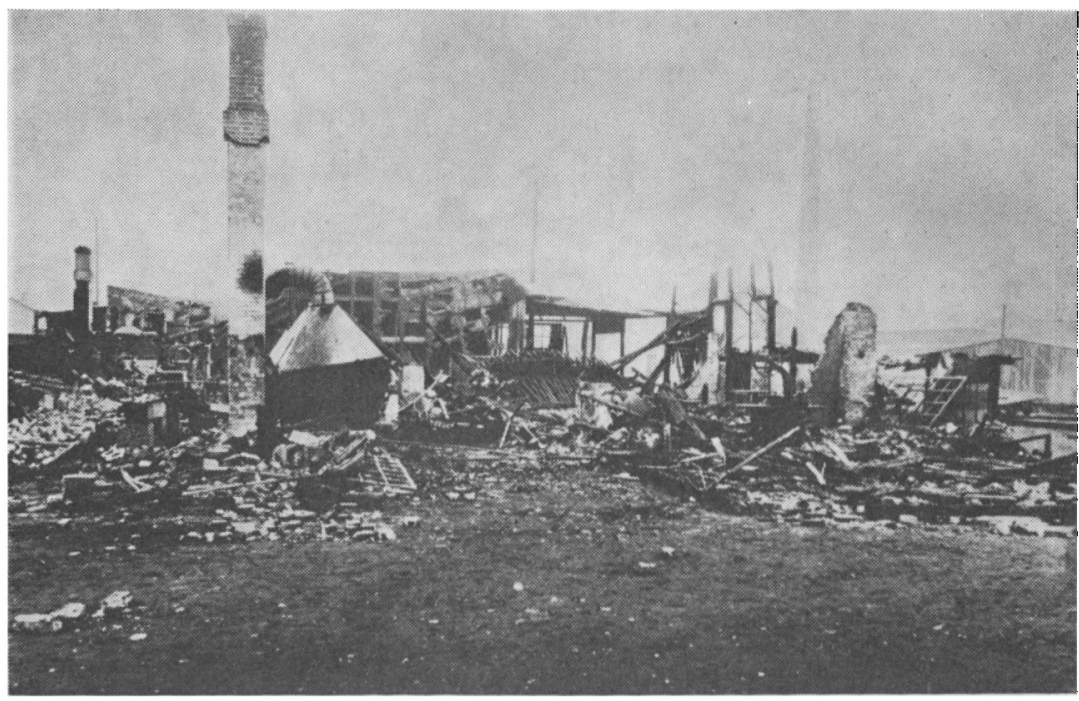

Sabotageaktionen mod fabrikken „DAPA“ den 28. december 1943 udfortes af et medlem af sabotageorganisationen BOPA, student Jesper Juel Petersen, mens han var hjemme på juleferie. Ideen var hans egen, sprangstoffet var medbragt fra Kobenhavn.

Dermed skiftede også modstandskampen karakter. Den hørte nu op med at være et indrepolitisk anliggende. Pá denne front havde den vundet sin sejr, og den kunne derefter indgå som et led i den fælles allierede strategi, hvilket faldt så meget mere belejligt, som den militære udvikling på fronterne nu også var moden dertil. Af denne grund kaldte England i efteråret 1943 sin repræsentant i Danmark, major Flemming Muus, hjem til London til ordremodtagelse.

Muus vendte i december 1943 tilbage til Danmark med nye direktiver, der gik ud på, at der her i landet skulle opbygges grupper $i$ et nyt og større omfang, end det hidtil havde været tilfældet. Disse grupper skulle ikke indlade sig $\mathrm{i}$ øjeblikkelige aktioner mod tyskerne, men uddanne sig $\mathrm{i}$ brugen af våben og sprængstof, hvoraf der blev lovet tilførsler, og iøvrigt afvente det øjeblik, da der over den engelske radio kom ordre til at gå i aktion mod forud udpegede mål. "Ventegrupper " eller >militærgrupper blev disse gruppers navn; senere kaldtes de også \R-grupper*. Hermed var der skabt en situation, hvis ekstra- 
ordinære karakter understregedes af bestemmelsen om, at der under opbygningen af disse grupper - som skulle være fuldendt til den 1. marts 1944 - og indtil videre skulle være sabotagestop i Danmark. Der skulle herske ro under opbygningen. Disse direktiver skabte herhjemme det indtryk, at der snart ville komme invasion, og at den ville komme i Danmark, og denne forventning om invasion var i forårshalvåret 1944 meget stor. Fra allieret side regnede man uden tvivl med, at denne forventning ville sive igennem til tyskerne og dermed bidrage til deres usikkerhed med hensyn til placeringen af den invasion, hvis forberedelser de var fuldt på det rene med.

Det var et led i det danske opbygningsarbejde, at ventegrupperne skulle samles $\mathrm{i}$ regioner, og at de foreløbigt passive sabotagegrupper også skulle knyttes hertil. Flemming Juncker påtog sig at organisere disse regioner for Jyllands vedkommende og fik derved en uformel placering som Jyllandsleder. Senere fæstnede denne post sig i den organisatoriske opbygning. Fra engelsk side var der planlagt tre regioner i Jylland, men i første omgang måtte Juncker gå frem, som de forhåndenværende muligheder bød det. Således kom Ribe amt under en særlig amtsledelse med sæde i Esbjerg, og i Vejle amt placerede han endog selvstændige byledelser i Vejle og Fredericia. Nordslesvig ønskede Juncker at samle under en fælles ledelse, og med dette formål for øje opsøgte han i januar 1944 farver Jacobsen, hvem han kendte gennem Dansk Samling.

\section{DEN FØRSTE REGION III}

Jacobsen gik straks ind på at overtage hvervet som leder af en nordslesvigsk region, og med ham som centrum blev der derpå dannet en regionsledelse. Det var en regel, der søgtes efterlevet overalt, at disse ledelser skulle være repræsentative $i$ modstandspolitisk henseende, således at de omfattede en kommunist, en Dansk Samling-mand og en trediemand uden for disse to partier. Dette lod sig dog langtfra gennemføre overalt, heller ikke i Nordslesvig. Den illegale organisation Ringen var på dette tidspunkt overhovedet ikke udbygget i Nordslesvig, og til de eksisterende Frit Danmark-grupper - således i Haderslev - havde Jacobsen intet kendskab. Han selv og Hans Mørup, som han bad 
Karakteristisk for nålestiksdemonstrationerne er det trakors, der den 22. august 1943 blev opsat på det sted uden for Abenrå, hvor en engelsk flyvemaskine godt et halvt ar tidligere var styrtet ned. Politiet konfiskerede korset og lod det foto. grafere i politigården. Det var opsat af kontorassistent Chr. Adolphsen, Rødekro.

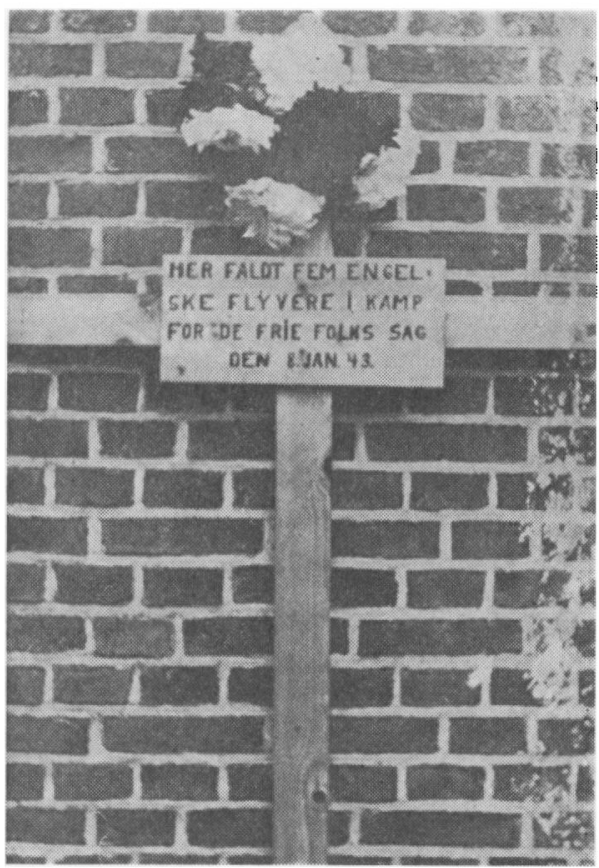

indtræde i ledelsen, kunne repræsentere Dansk Samling, og Juncker lovede, at en kommunist skulle blive tilforordnet den nye regionsledelse. Det blev arbejdsmand Kai Ibsen, der stammede fra Kolding, og som på dette tidspunkt arbejdede illegalt $i$ det sydlige Nørrejylland. Han tiltrådte regionsledelsen i slutningen af februar 1944 og bragte dermed området fra Kolding i ost til Esbjerg i vest i forbindelse med den åbenrå'ske regionsledelse, hvilket var så meget mere à propos, som amtsledelsen for Ribe amt netop omkring den 1 . marts 1944 blev revet op af tyskerne. I løbet af februar 1944 blev også en officer knyttet til regionen, nemlig kaptajn $K$. Kjeldsen, der iøvrigt havde spillet en fremtrædende rolle $i$ terrænsportsbevægelsen. Baggrunden for hans tilknytning var, at Juncker af den illegale hærledelse, den såkaldte slille generalstab , havde fået stillet nogle officerer til rådighed for sit jyske opbygningsarbejde. Kjeldsen skulle overtage den militære ledelse af sabotagen i regionens område, således at jernbanetrafikken og telefon- og telegrafforbindelsen kunne 
afbrydes. Da sabotagen foreløbig var skrinlagt, ville det i praksis sige, at han skulle udpege objekter og planlægge aktioner imod dem.

Dermed var Region III skabt. Da den havde sit centrum i Ảbenrå, var det naturligt, at den også havde sit tyngdepunkt i Nordslesvig, og at forbindelsen til fjerne byer som Ribe, Esbjerg, Varde og Kolding undertiden var så spinkel, at den kunne synes at være helt afbrudt. Gennem Kai Ibsen lykkedes det dog at opretholde en forbindelse mellem disse byer og regionschefen. En stor ulempe var det, at Kjeldsen boede i Assens og derfor ikke kunne have konstant forbindelse og føling med det forberedende arbejde. Regionslederen havde et nært samarbejde med det illegale arbejde i Tønder og Haderslev, hvorimod der ikke fandtes nogen som helst kontakt til Sønderborg og Als. Mest intensivt blev arbejdet - naturligvis - drevet i Åbenrå by og amt.

Det faldt helt af sig selv, at Jacobsen og Mørup bad deres gamle, prøvede medarbejdere fra kredsens terrænsportsarbejde påtage sig de illegale opgaver, der skulle løses nu, da regionen var blevet dannet, og invasionen formodedes at stå for døren. Forbindelserne til Tønder blev overdraget til kontorassistent Svend Aage Lyck, mens opbygningen af grupper i Åbenrå blev overladt til landbrugskandidat, løjtnant Jørgen Poulsen, der gennem sit arbejde som leder af terrænsportsafdelingen havde erhvervet sig et indgående personalkendskab. Mørup tog sig af forbindelserne på østkysten, mens den ganske unge bankassistent Sven Hoffmann fungerede som hans kurér og tillige som våbenog sprængstofinstruktør.

Ligesom den regionsstab, der sprang frem som følge af et pludseligt opstående behov, uden forudgående overvejelser eller beregninger udgik fra Åbenrå-kredsens og terrænsportens rækker, således blev gruppedannelsen også tættest og mest omfattende i Abenrå by og amt. Her kendte man sine folk, her var den fornødne tillid forlængst til stede som et produkt af de foregående års samarbejde. Derfor kunne der $i$ denne fase af arbejdet $i$ dette område opstå et net af grupper, der $i$ tæthed ikke blev overgået $p a ̊$ noget senere tidspunkt $i$ det illegale arbejde. I løbet af månederne februar, marts og april 1944 gennemførtes opbygningsarbejdet $i$ et stadigt kapløb med den tidsfrist, der var 
sat af den forventede invasion, indtil man $i$ april kunne gøre foreløbig status over de resultater, der var nået. I Ảbenrå var der skabt 13 grupper. Af disse var fire dannet ud fra terrænsportsafdelingen og regnedes for sabotagegrupper. De ovrige var ventegrupper. De fem af dem var dannet blandt Forsvarsbrødrene og stod under ledelse af deres formand, liniemester Thomas Christiansen, mens de resterende fire var fra Sct. Georgsgildet og lededes af gildemesteren, købmand Johs. M. Petersen. Spredt over amtet fandtes grupper $i$ en række byer og landsbyer, nemlig $i$ Løjt Kirkeby, Hellevad, Bolderslev, Rødekro, Sdr. Hostrup, Røllum, ${ }^{10}$ Kruså, Tinglev og Gråsten. Sidstnævnte sted regnede man med to grupper. De fleste af disse grupper var skabt på grundlag af terrænsportsarbejdet. Et par af dem var en arv fra den Bøge'ske organisation, nemlig grupperne i Kruså og Tinglev.

Parallelt med gruppeopbygningen gik arbejdet med at instruere $i$ anvendelsen af våben og sprængstof og med at udpege de objekter, mod hvilke der efter kodesignal fra London skulle iværksættes aktioner. I april 1944 ankom der våben og sprængstof til Ảbenrå, afsendt pr. bane som "maskingods « fra Viborg. Det blev udlagt $i$ depoter til senere anvendelse. Regionen var nu klar til at træde $\mathbf{i}$ aktion.

\section{DET BOECK'SKE INITIATIV PA NY}

Denne summariske skildring kan ved sin mangel på detailler give det indtryk, at det illegale arbejdes opbygning var præget af ensartethed, og at det gennemløb en jævn, kontinuerlig udvikling uden forvirrende og tværgående initiativer til at tilsløre det klare billede. Dette var ingenlunde tilfældet. Overalt i landet blev klarheden tilsløret af et pludseligt illegalt initiativ, der uventet kunne dukke op og gøre sig gældende. Dette er der eksempler på også i Ảbenrå.

I København var orlogskaptajn Wilh. Nellemose i efteråret 1943 i gang med at opbygge en illegal organisation, som han også søgte at udbygge $i$ provinsen. Han erhvervede via kurerer kontakter i Nordslesvig, således i Sønderborg og Ảbenrå. Sidstnævnte sted blev et samarbejde indledet med kriminalbetjent Jørgen Nielsen, men Nellemoses arrestation i begyndelsen af 1944 satte definitivt bom for disse bestræbelser. 
Vigtigere for Åbenrås vedkommende blev overretssagfører Boecks sabotageplaner. Det initiativ, han havde udfoldet, havde som foran nævnt ikke ført til noget resultat i forste omgang, og han søgte derfor i efteråret 1943 på ny kontakt opefter. Da de forste fremmede sabotører var kommet fra Esbjerg, var det naturligt, at han søgte kontakter i denne by. Gennem en derværende Dansk Samling-mand lykkedes det ham at fả forbindelse med den lokale Frit Danmark-gruppe, og denne lovede ham hjælp og støtte. Det er bemærkelsesværdigt, at de sabotagefolk, der nu blev sat $i$ gang med opgaven, tildels var de samme som første gang. Ganske vist var kommunisternes illegale apparat $i$ Esbjerg blevet revet grundigt op i tiden omkring den 1. september 1943, men deres filialgruppe i Varde bestod uantastet og opererede i efteråret og vinteren 1943 i meget nært samarbejde med SOE's lokale repræsentant, Aage Møller Christensen. Under hans ledelse gik Varde-sabotørerne i gang med forberedelserne til en sabotage i Åbenrå. Maskinarbejder Viggo Hansen, der havde været med i Åbenrå i sommeren 1943, aflagde atter besøg i byen - første gang ved juletid 1943 - og forberedte i samråd med Boeck en aktion mod Åbenrå Motorfabrik, idet fabrikken Hamag blev medinddraget $i$ forberedelserne. I Varde havde man allerede tidligere haft samarbejde med den københavnske sabotageorganisation Holger Danske, og dennes assistance blev ogsâ påkaldt til denne aktion. Boeck skaffede anløbssted og natlogi til de udefra kommende folk, ligesom han fik fat i fire lokale folk, der skulle være vejvisere og medhjælpere under aktionens gennemførelse.

I week-end'en den 5.-6. februar 1944 gennemførtes aklionen, der fik så ulykkelige konsekvenser. Dens gennemførelse på trods af det da gældende sabotageforbud skyldtes et sammentræf af misforståelser og uheldige omstændigheder. Det er i denne forbindelse værd at bemærke, at to af de fire lokale hjælpere havde meget nær tilknytning til den nydannede regionsledelse og dermed kendskab til sabotageforbudet. Når regionsledelsen alligevel ikke skred ind og hindrede aktionen - og heller ikke gjorde forsøg på det, er det et vidnesbyrd om, i hvor høj grad man i det illegale arbejde passede sine egne sager og ikke blandede sig i andres dispositioner, når de ikke angik en selv. Det lokale ræson- 
nement har været dette, at når en sådan aktion overhovedet lod sig gennemføre midt $\mathrm{i}$ en periode med sabotagestop, og når en række udenbys sabotører kom rejsende til for at udføre den, mâtte alle nødvendige forudsætninger være $\mathbf{i}$ orden.

Det kom ikke til at gå efter planerne. Aktionen mod Hamag blev ganske vist en succes, men mod Abenrå Motorfabrik mislykkedes den ganske. Over for sabotagevagterne gik overraskelsesmomentet tabt; under udlægningen af bomberne ankom alarmerede danske politifolk; og som følge af det opståede kaos mislykkedes antændelsen af bomberne, så at ingen af dem sprang. Endelig lykkedes det heller ikke midt $i$ forvirringen og nervøsiteten at fordele de fremmede sabotører efter den lagte plan blandt de forskellige logiværter, men de fleste endte atter hos automobilhandler Peter Koch, Styrtom, hos hvem de var anløbet om lørdagen.

Under en drøftelse af situationen blev sabotørerne enige om at gentage aktionen om aftenen den næste dag, søndag. En mand blev sendt til Fredericia efter mere sprængstof. Han blev på vejen ind til Åbenrå arresteret af tyskerne, men undslap fra dem. Kort efter omringede tyskerne Kochs hus. Sabotørerne skjulte sig $i$ et udhus, men blev opdaget. Det lykkedes dem dog under ildkamp at undslippe, men tyskerne havde held til at følge de flygtendes spor, at fange et par af dem og at foretage yderligere arrestationer i Varde. Som en udløber heraf blev Frit Danmarkgruppen i Esbjerg også til dels revet op. Prisen for aktionen blev alt $i$ alt høj: En af deltagerne døde under ildkampen, flere blev såret og mange arresteret, deriblandt Koch og hans husbestyrerinde. Boeck måtte flygte og kom til Sverige, hvilket også blev tilfældet med SOE-manden Moller Christensen. ${ }^{11}$

Også for politiet fik aktionen eftervirkninger. De alarmerede politibetjentes samarbejde med sabotørerne under aktionens videre forløb kom til tyskernes kundskab, og de blev arresteret af dem. Selv om det hurtigt lykkedes at få dem løsladt, bidrog sagen dog til at styrke tyskernes generelle mistillid til det danske politi. ${ }^{12}$ Endelig kan det nævnes, at denne sabotage blev benyttet som motivering for den allerede forinden overvejede oprettelse af Selbstschutz-korpset inden for det tyske mindretal. ${ }^{18}$ 


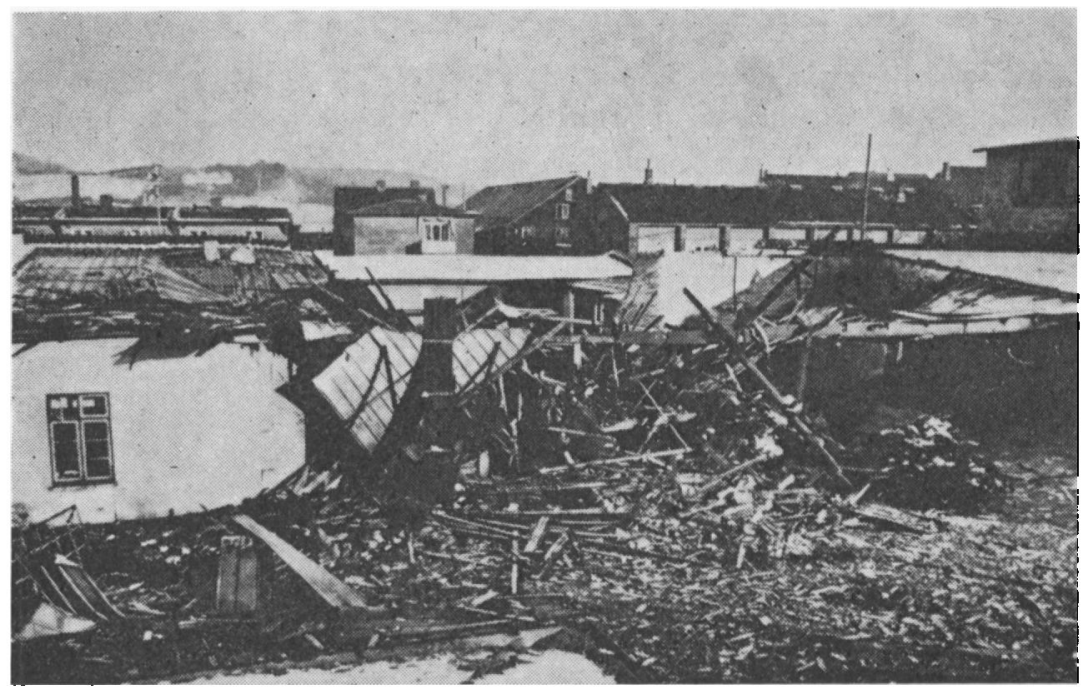

Mens aktionen mod Abenrå Motorfabrik (Callesen) mislykkedes, fik aktionen den 5.-6. februar 1944 mod fabrihken "HAMAG" det resultat, billedet viser.

\section{GENERALPRØVE OG OPRULNING}

Den mislykkede aktion fik ingen konsekvenser for regionsledelsen og dens opbygningsarbejde. Skønt lokale folk med nær tilknytning til ledelsen havde været de fremmede sabotører behjælpelige, medførte arrestationerne ingen indgang for tyskerne til den. En oprulning ville også have været fatal for det arbejde med at formere og uddanne grupper, som netop på det tidspunkt var $i$ sin vorden.

Søndag den 30. april 1944 fik farver Jacobsen besøg af oberstløjtnant Vagn Bennike. Denne havde, efter at Flemming Juncker i løbet af april havde mâttet forlade landet, overtaget posten som Jyllandsleder. Bennike opsøgte Jacobsen for at meddele ham, at de koder, der skulle udløse de planlagte aktioner, havde været udsendt over BBC den foregående aften, og at aktionerne skulle finde sted den følgende nat. Da regionsledelsen i Abenrå ikke havde fået kodeordene udleveret, måtte Bennike selv rejse til byen for at få aktionerne udlost, og regionsledelsen måtte derpå i huj og hast alarmere sine grupper, såvel de indenbys som de udenbys. Lyck måtte afsted til Tønder, Hoffmann til Haderslev. 


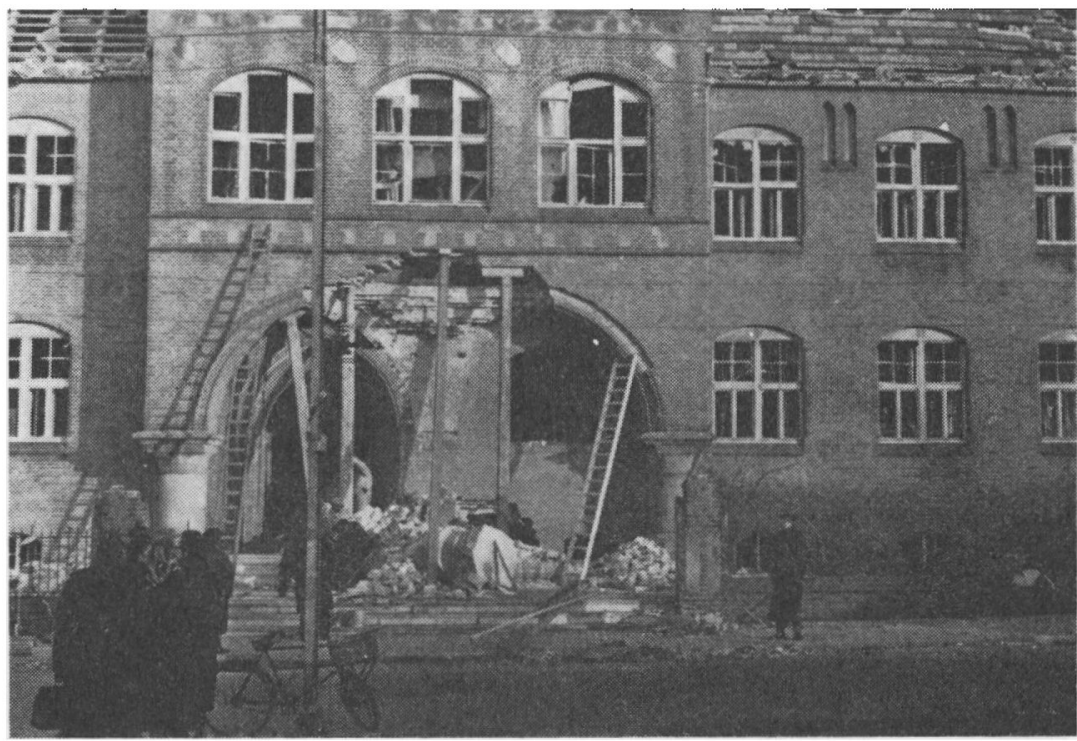

Som havnaktion for sabotagen mod „HAMAG“ og Abenrå Motorfabrik i februar blev politistationen $i$ Abenrà udsat for ,schalburgtage“ den 5. maj 1944, foretaget af Gestapo. Odelaggelserne var meget store, som det fremgär af billedet af indgangsportalen.

I Åbenrå var man sikker på, da man skred til udførelsen af de forberedte aktioner, at nu kom invasionen - den længe ventede.

Natten til den 1. maj 1944 mellem kl. 3,40 og kl. 7,15 sprængte Ảbenrå-folkene otte telefonpæle på strækningen langs Oksevejen fra Rødekro til syd for Bolderslev, en telegraf- og telefonmast umiddelbart syd for Rødekro og en dobbeltmast til højspændingsværkets ledning nord for Åbenrå. Tinglev-gruppen sprængte tre telegrafpæle ved Terkelsbøl og to telefonpæle ved Tinglev. Tilsvarende ødelæggelser anrettedes ikke blot $\mathrm{i}$ regionens øvrige område, men også forskellige steder i Jylland. Nogle steder tvivlede man dog på ordrens seriøse karakter og nægtede at udføre den, således i Ålborg og Århus. Alle aktionerne var rettet mod tyskernes kommunikationslinier. Der, hvor man havde troet på alvoren bag ordren, var skuffelsen stor, da det viste sig, at invasionen alligevel ikke fulgte efter. Der var kun tale om en "generalprøve * på organisationens effektivitet, iværksat fra engelsk side. Eller der var måske snarere tale om een blandt mange andre allierede 


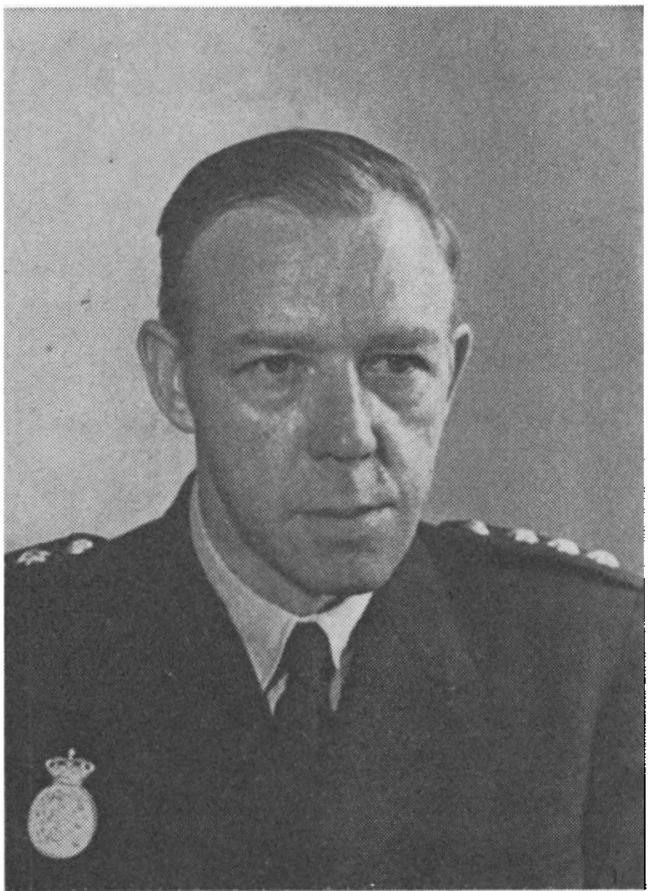

Politimester Aage Agersted, hvis position og anseelse $i$ Abenrả og ud over den nordslesvigske landsdel var meget betydelig, dels $i$ kraft af, at han var attacheret politiadjudanten $i$ de sonderjyske landsdele, amtmand $\mathrm{Kr}$. Refslund Thomsen, dels pai grund af sin starke personlighed. I 1943 udnæevntes han til chef for ordenspolitikommandoen $i$ Jylland med sade $i$ Arhus og fik her et nort illegalt samarbejde med Flemming Juncker. Den 30. maj 1944 blev han arresteret som et led $i$ „politimesteraktionen". Han dode $i$ koncentrationslejren Neuengamme den 2. december 1944.

vildledningsmanøvrer for at øge tyskernes usikkerhed med hensyn til invasionsstedets beliggenhed.

>Generalprøven « blev regionsledelsens eneste lejlighed til at komme i aktion. Inden den atter fik mulighed for at sætte sine grupper i aktivitet, blev den revet op af tyskerne. Disse gennemførte nemlig den 26. maj 1944 den såkaldte spolitimesteraktion «, således kaldt, fordi der blandt de arresterede var en række fremtrædende politiembedsmænd. ${ }^{14}$ Tyskerne tilsigtede hermed dels at neutralisere den føromtalte P-ordning, som de havde kendskab til, dels at ramme den militære efterretningstjeneste. Et led i deres aktion var forsøget på at arrestere chefen for Grænsegendarmeriet, oberst S. B. Paludan-Müller, Gråsten, der blev dræbt efter en langvarig kamp.

Tyskerne fik en uventet ekstragevinst ud af deres arrestationer, idet de fik indgang i Region III's ledelse med det resultat, at også denne blev revet op. Farver Jacobsen, Svend Aage Lyck

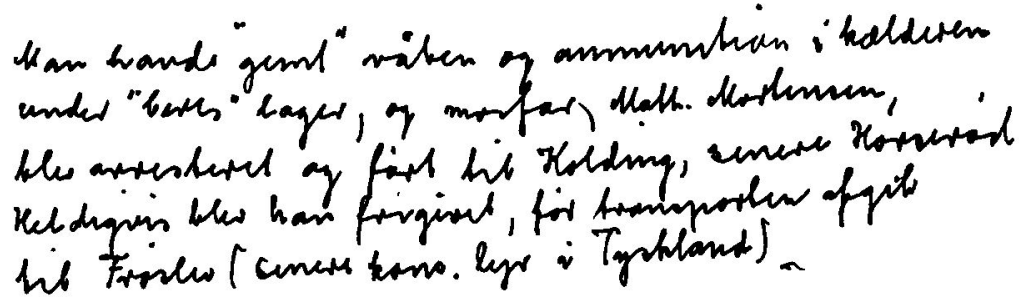


og Sven Hoffmann havde held til at undgå tyskernes eftersøgning af dem. Men bortset fra dem blev regionsledelsen taget af tyskerne, og det kom ikke til at gå ud over den alene. Langt ned i rækkerne i Åbenrå og byens opland ramte arrestationerne, og de oprettede grupper blev enten revet op eller neutraliseret. Samtidig blev størstedelen af de våben og det sprængstof, der var blevet sendt til byen, konfiskeret af tyskerne. Da efterforskningsarbejdet var til ende, kunne de tyske myndigheder i Danmark med stolthed indsende en særrapport til Berlin, hvori de bl. a. meddelte, at de havde arresteret 36 mennesker og beslaglagt 55 geværer, 30 maskinpistoler, 20.000 skud ammunition, $98^{1 / 2} \mathrm{~kg}$ sprængstof $\mathbf{m}$. v.

Den tyske succes var fuldstændig, og genopbygningsarbejdet måtte begynde på helt bar bund.

\section{DEN IVERSEN'SKE REORGANISERING.}

Midt under arrestationshølgen kom Jyllandslederen, Vagn Bennike, til Åbenrå for at konferere med farver Jacobsen. Han dumpede midt ned i kaos og forvirring og blev hurtigt klar over, at der ikke længere eksisterede nogen regionsledelse, for den sags skyld heller ikke nogen region. "Jeg rejste straks fra byen, tilkaldte premierløjtnant Iversen og pålagde ham at genopbygge organisationen i landsdelen".

Premierløjtnant B. B. Iversen havde siden den 1. maj 1944 arbejdet under Bennike som kurér og instruktør i Jylland og derved fået en række kontakter også i Region III. De fleste af disse forsvandt $i$ den store oprulning $i$ maj og juni 1944, men enkelte var dog tilbage, og på grundlag af disse og ved at dyrke en række nye kontakter op lykkedes det Iversen at få arbejdet på benene igen. Han fik til sin hjælp to andre officerer, således at kaptajnløjtnant Jørgen Gabriel-Jensen blev distriktsleder på vestkysten med sæde i Esbjerg og premierløjtnant Alfred Rasmussen Friis distriktsleder $\mathbf{i}$ området langs grænsen med sæde i Abenrå. Endvidere bestod den nye regionsledelse af montør Vagn Merrild Jensen, Odense, som kommunisterne indsatte som deres repræsentant til afløsning af den arresterede Kai Ibsen. Regionens nordgrænse forskubbedes i denne periode mod nord, således at den også omfattede byerne Fredericia, Vejle og Grind- 
sted. Iversen slog sig ned i Kolding. Han udforte sit illegale arbejde i meget nært samarbejde med Bennike, der kunne holde så meget nærmere føling med det, som han indtil september 1944 havde illegal bopæl i Vejle. Ja, i sine telegrammer til England omtaler Bennike ligefrem Iversen som $\sin$ »underleder" for Fredericia, Kolding og Lunderskov og sstedfortræeder i Sydjylland «.

Ligesom den Jacobsen'ske regionsledelse havde været behersket af forventningen om den invasion, der skulle finde sted på den jyske vestkyst og befri Danmark, således levede den Iversen'ske ledelse $i$ troen på et snarligt tysk sammenbrud. Det var ikke en tro, der var specielt sydjysk. I sine telegrammer til England gav Bennike gang på gang udtryk for den, når han berettede om de forholdsregler, man planlagde. Således hed det i et telegram af 17. august 1944: "Hele Jylland klar til aktion. Har nødvendige sprængstoffer. Har nedkasteplaner for vảben, når fjenden er i oplosning eller går «. Og tilsvarende telegraferede Bennike den 23. august: "Vil fjenden gå, pâtænker vi at afbryde banen ved Tonder og Bajstrup for at hindre bortførsel af materiel m. m. .

Fra England blev der slået koldt vand i blodet, idet man gjorde opmærsom på, at rygter om tysk evakuering af Danmark kunne være inspirerede af tyskerne selv med det formål at lokke modstandsbevægelsens folk ud af busken. Imidlertid havde man i London øjensynligt intet at indvende mod de forberedelser, der under Bennikes tilsyn blev truffet langs grænsen, og som blev således opsummeret $\mathrm{i}$ et telegram den 29. august 1944: "Hvis tyskerne forlader Danmark i opløsning, vil vi ved passive spærringer på alle sydgående småveje syd for vejen Kruså-Tønder få dem til at samle alt materiel disse to steder. Her spærres også grundigt, og væbnede danske styrker sørger for, at materiel efterlades «. De passive spærringer, som Bennike omtalte, omfattede også ødelæggelse af jernbanebroerne over Vidå, Bredeå og Brønså i det vestlige Sønderjylland og af jernbanebroer ved Padborg, Bajstrup og Sommersted i øst.

Ved siden heraf blev der også forberedt øjeblikkelige sprængninger af jernbanerne til forsinkelse af den tyske militære trafik, og det var nok noget, man fra allieret side var umiddel- 
bart mere interesseret i. Således telegraferede London til Bennike den 5. september 1944: "Situationen i Finland vil påvirke fjendens dispositioner. Store troppebevægelser kan komme gennem Danmark. Vær rede til forsinkelsesaktioner".

Der var følgelig fortsat behov for to slags grupper - sabotagegrupper til øjeblikkelig indsættelse mod først og fremmest jernbanetrafikken og ventegrupper til indsættelse $i$ den sammenbrudssituation, man regnede så kraftigt med og forberedte sig så grundigt på. Rundt om i regionens forskellige byer gik man i gang med at formere grupper på ny - også i $\Lambda ̉$ benrå.

\section{GENOPBYGNING, SABOTAGE OG FRIK'TION}

Skildringen af den måde, hvorpå det illegale arbejde $\mathrm{i}$ og omkring Abenrå endnu engang blev genopbygget og de hertil fornødne kontakter etableret, giver et typisk billede af de vilkår, dette arbejde havde at virke under, og af de metoder, det måtte gå frem efter.

Iversen havde af Bennike fået en kontakt i Lunderskov, fra hvilken han via dennes familieforbindelser fik forbindelse med kontorassistent Christian Adolfsen, Rødekro. På samme tid var pastor Sigfred Riishøjgaard, der var blandt dem, der i maj/juni 1944 ved at gå under jorden havde unddraget sig arrestation, illegalt i Aabenraa i forsøg på at reorganisere arbejdet og skabe nye kontakter, og han fik forbindelse med Adolfsen samme dag, som denne ventede besøg af Iversen om aftenen. Forinden havde Riishøjgaard haft kontakt til overlæge J. M. Wollesen og assistent Nis Enemark. Resultatet af alle disse kombinationer var, at der den 27. juli 1944 om aftenen holdtes et møde i Rise skov mellem Iversen, Adolfsen, Wollesen, Riishøjgaard og Enemark. Mødet endte med, at Iversen meddelte Wollesen, at der skulle komme nærmere besked til ham.

Selv om der ikke var hændt det tilfældige sammentræf, at Adolfsen kunne føre sin sognepræst og den mand, hans svoger i Lunderskov sagde god for, sammen, ville en forbindelse fra Åbenrå opad være kommet $\mathrm{i}$ stand alligevel. Riishøjgaard havde inden sit underjordiske besøg i Åbenrå været i København, hvor han gennem ledende Dansk Samling-folk som Robert Stærmose og Anker Olesen havde fået en indgang til Bennike i Vejle. 
Netop den her beskrevne blanding af bevidst søgen efter kontakter og de rene tilfældigheders lunefulde spil var karakteristisk for det illegale arbejde.

Der var imidlertid også andre, der arbejdede på at retablere organisationen. Gennem sit parti fik Merrild Jensen forbindelse til arbejdsmand Julius Berndt i Ảbenrå og gennem denne videre til den unge telefonmontør Egon Nørgaard. Også Sven Hoffmann optrådte som kontaktformidler. Efter at være gået under jorden i juni 1944 tog han til København, hvor han fik forbindelse med Frode Jacobsens illegale organisation, Ringen. Hoffmann aftalte med Frode Jacobsen, at han skulle rejse til Nordslesvig for at genopdyrke så mange gamle kontakter som muligt og knytte dem til Ringen. Efter at have været i Haderslev og Ribe fik han forbindelse med Bennike, som han talte med $i$ Vejle. Udstyret med de oplysninger, som denne kunne give ham, kom Hoffmann derefter - formentlig ganske kort tid efter den 27. juli 1944 til Åbenrå, hvor han tog ind hos dommerfuldmægtig Erik Bondo Svane, ${ }^{15}$ hvis aktivistiske indstilling han var orienteret om fra deres fælles pensionatstilværelse. Svane indkaldte derpå til et møde, hvor Wollesen og politifuldmægtig Ivar Møller førtes sammen med Hoffmann, og på dette møde konstitueredes en ny byledelse for Ảbenrå. Wollesen blev indsat som byleder, mens Bondo Svane skulle varetage kontakten til byens ungdomsforeninger med henblik på ventegrupper og Ivar Møller forbindelsen til politiet, hvilket dog ikke blev den umiddelbare succes, som man havde ventet.

Til byledelsen knyttedes også Nis Enemark som sabotageleder, men denne funktion blev ikke realiseret. Da Iversen nemlig senere kom til Åbenrå sammen med Rasmussen Friis for at indføre denne hos Wollesen, benyttede han lejligheden til at kontakte Egon Nørgaard, som Merrild Jensen havde givet ham indgang til, og Rasmussen Friis og Nørgaard blev koblet sammen i et samarbejde. Nørgaard var ganske vist een af dem, som Enemark havde haft i tankerne med henblik på sabotage, men som kontakterne havde udviklet sig, blev der i praksis ikke tale om nogen koordination eller noget samarbejde mellem Wollesens byorganisation og de oplandsgrupper, som Egon Nørgaard fik dannet i Rødekro, Bolderslev, Hjordkær, Bajstrup, Tinglev og 
Dommerfuldmogtig Erik Bondo Svane (1911-45), medlem af den illegale byledelse $i$ Abenrå julioktober 1944, arresteret den 19. okt. 1944, ded $i$ koncentrationslejren Dessauer Ufer den 5. marts 1945.

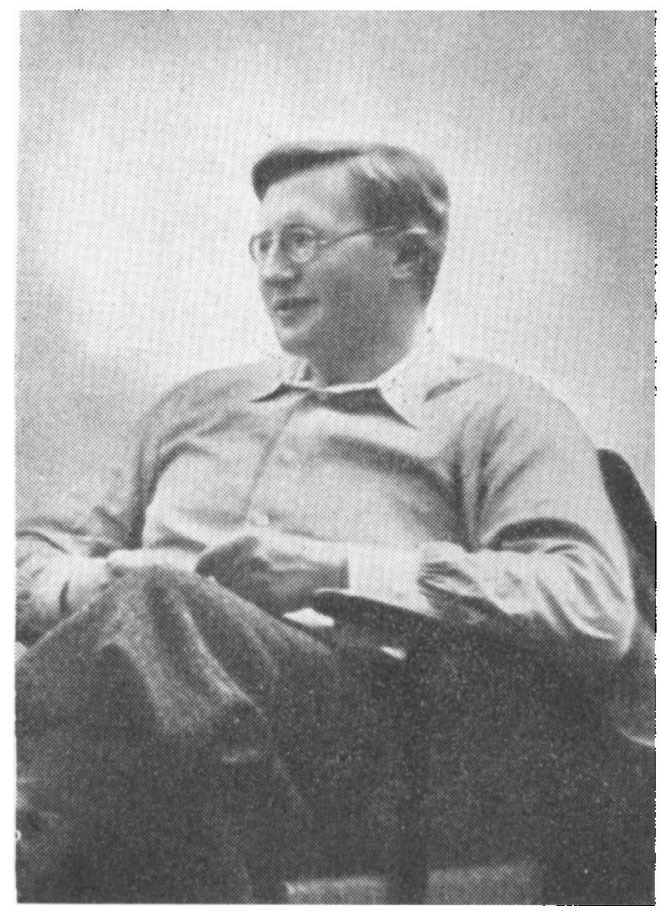

Fårhus - Gråsten levede $\mathrm{i}$ resten af besættelsestiden sit eget illegale liv. For Norgaards vedkommende gik forbindelsen opad direkte til Rasmussen Friis bortset fra den stadig vedligeholdte kontakt til Merrild Jensen.

Egon Nørgaard havde for sin overgang til sabotagevirksomhed sammen med trafikassistent Børge Andersen, Bolderslev, startet det eneste illegale blad, der under krigen blev udgivet lokalt $i$ Abenrå-området. I maj 1944 udkom i Bolderslev det forste nummer af "Budstikken «, om hvis proveniens bladet oplyste: "Udgivet af Danmarks kommunistiske Parti. Haderslev. Ảbenrå. Sønderborg " ${ }^{16}$ Indholdet var dels eftertryk af artikler fra de store illegale landsblade (herunder Frihedsrådets meddelelser), dels lokalt nyt. Bladet spillede en væsentlig rolle for etableringen af strejke, først og fremmest blandt jernbanepersonalet, $i$ området fra grænsen op til Fredericia og Varde, da den forste transport af fanger den 15. september 1944 afgik fra Froslev til koncentra- 


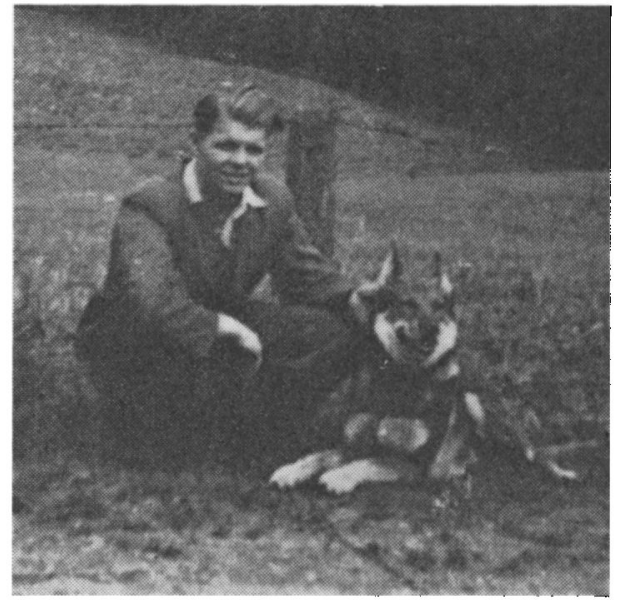

Egon Nergaard (1923-44), sabotageleder $i$ Abenrå august-oktober 1944, arresteret den 17. oktober 1944, skudt "under flugtforseg" den 8. december 1944 på Skrydstrup flyveplads.

tionslejr i Tyskland. Bladet udkom månedligt indtil oktober 1944, da det på grund af arrestationer efter en pause overgik til en ny redaktion med hjemsted i Haderslev.

Forholdet mellem kommunister og ikke-kommunister i modstandskampen er ofte gjort til genstand for diskussion, og der har i efterkrigstiden undertiden været en tendens til at projicere senere opståede modsætningsforhold bagud til krigstiden. Det normale var et godt og gnidningsløst samarbejde rettet mod den fælles fjende. For Region III's vedkommende lader det sig imidlertid ikke afvise, at der $\mathrm{i}$ denne periode eksisterede et udtalt modsætningsforhold de to parter imellem. Det gælder såvel på regionsplanet, hvor forholdet mellem Iversen og Merrild Jensen var præget af gensidig mistillid, som på det lokale plan, bl. a. i Åbenrå, hvor samarbejdet mellem Rasmussen Friis og Egon Nørgaard, som oprindeligt havde været Merrild Jensens kandidat til bylederposten i Ảbenrå, forløb alt andet end friktionsfrit. Begge parter mistænkte modparten for at pleje private særinteresser og tog sine forholdsregler derimod.

Den gensidige animositet fik dog ingen indflydelse på kampen mod tyskerne. Tværtimod er denne periode præget af en aktivitet, der var endog meget livlig, efter at der forst var kommet stof til at arbejde med. I midten af august 1944 modtog Egon Nørgaard fra Merrild Jensen en lille sending våben og sprængstof, 
men først da der den 9. september 1944 var kommet en sending pâ $3-400 \mathrm{~kg}$ sprængstof til Hjordkær station, var forudsætningen for en virkelig offensiv mod jernbanetrafikken til stede. Følgende oversigt viser den indsats, som denne periodes sabotagegrupper gjorde. To datoer ud for en aktion markerer, at aktionen er foretaget $i$ den mellemliggende nat: ${ }^{17}$

Dato

Aktionens art

Afbrydelsens varighed i timer

14. aug. Skinne losnet Bolderslev-Hjordkar ........ opdaget 16/17. aug. Sporskiftesprængning Hjordkær station ..... 9 26/27, aug. Formodet sabotage Bolderslev-Hjordkær

4/5. sept. Jernbanebroen over Uge bæk sprængt ...... 19

9/10. sept. Jernbanebroen over Uge bæk sprængt ...... 17

Sporskiftesprængning Bolderslev station ......

Sporskiftesprængning Hjordkær station ...... Sporskiftesprængning Fårhus station ........ Sporskiftesprængning Rødekro station ....... Sporskiftesprængning Hovslund station ...... 17 Sporskiftespræengning Bajstrup station (forsager) Skinnesprængning Rødekro-Hjordkær i km 81,4 Sprængning af lastbil, Rødekro ...........

14/15. sept. Sporskiftespræengning Bajstrup station ...... 6 Formodet sabotage Tinglev-Bolderslev ...... 21/4

15/16. sept. Sporskiftesprængning Bolderslev station ..... 2

16/17. sept. Formodet sabotage Tinglev-Bolderslev ...... $5^{1 / 2}$

17/18. sept. Sporskiftesprængning Hovslund station ...... 6

18/19. sept. Sporskiftesprængning Bolderslev station ..... 7

21/22. sept. Skinnesprængn. Over Jerstal-Hovslund i $\mathrm{km} \mathrm{67,2} 9$

24/25. sept. Sprængning af tysk lokomotiv, Padborg

25/26. sept. Togafsporing Rødekro-Hjordkær ......... $44^{3 / 4}$

27/28. sept. Togafsporing Bolderslev-Hjordkær i $\mathrm{km} 87,5 \quad 42$

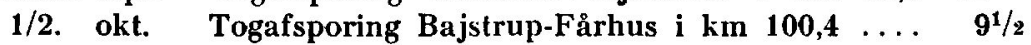

6/7. okt. Togafsporing Rødekro-Hjordkær i km 82,8 ... 35

22. okt. Sprængning af tysk lokomotiv, Padborg.

Betegnelsen ,i km" angiver det nøjagtige punkt p\$ strzkningen, hvor cabotagen fandt sted.

Denne kortvarige, men hektiske aktivitet udgik fra oplandsgrupperne og lededes af Rasmussen Friis og Egon Nørgaard. Således var natten til den 10. september samtlige grupper $\mathrm{i}$ sving efter ordre fra Rasmussen Friis. Det siger sig selv, at denne lokale indsats var koordineret med tilsvarende aktioner $i$ den øvrige del af regionen. Denne jernbanesabotage var ingenlunde i stand til at standse de tyske transporter, men den kunne tilføje 
dem betydelige forsinkelser og volde afbræk i de lagte køreplaner.

Parallelt med denne sabotage gik arbejdet med at forberede det ventede tyske sammenbrud. Om disse forberedelser koncentrerede byledelsen i Åbenrå sig på grundlag af de instrukser, den modtog herom. Nye ventegrupper skabtes, og andre genoplivedes, således at der $i$ september 1944 fandtes 90 mand i 15 grupper. Disse grupper skulle, når tidens fylde var inde, spærre Hovedvej 10 både nord og syd for byen, afbryde telefonkabler, specielt det tyske Norges-kabel, besæelte rådhuset, posthuset $\mathrm{m}$. v. og afbryde strømmen pâ Højspændingsværket. Politiet, som man omsider fik den onskede forbindelse til, skulle neulralisere Gestapo. Til brug for grupperne i Åbenrå by ankom seks kasser med vảben. De blev foreløbigt samlet oplagret på sygehuset, camoufleret som beredskabskasser fra Det civile Luftværn.

\section{OPRULNING OG REORGANISERING EEN GANG TIL}

Imidlertid blev hele denne aktivitet - sâvel den øjeblikkelige som den, der tog sigte på krigens afslutning - brat standset som følge af den arrestationsbølge, der i dagene fra den 5. oktober 1944 fremefter rullede hell over Region III og rev både regionsledelsen og samtlige byledelser over ende. Regionslederen selv, B. B. Iversen, blev arresteret, og da Bennike søgte at rette situationen op ved at indsætte Rasmussen Friis som hans efterfølger, havde tyskerne held til også at arrestere ham, før han havde fảet lejlighed til at gøre en indsats. Af regionsledelsens medlemmer undgik kun Merrild Jensen arrestation og kunne enkelte steder som i Esbjerg og Haderslev bevare kontinuiteten i arbejdet. Ảbenrả var blandt de byer, arrestationerne hjemsøgte. Wollesen og Egon Nørgaard blev straks arresteret, mens Ivar Moller og Nis Enemark gik under jorden og forsvandt fra byen. Ca. to uger senere end de ovrige blev ogsá Bondo Svane arresteret, men havde forinden da haft lejlighed til at videregive sine kontakter. I regionens område som helhed konfiskerede tyskerne bl. a. 2 tons sprængstof, 253 maskinpistoler og 61 maskingeværer. For Åbenrås vedkommende blev depoterne på sygehuset og i Hjordkær konfiskeret. Som i juni 1944 måtte arbejdet begynde gennemgribende forf ra.

Det eneste lyse punkt i det mørke billede var en række kon- 
takter, som organisationen Ringen havde skabt rundt om i regionens omráde. Siden forâret 1944 havde kaptajn Aage Højland Christensen arbejdet som organisator af mililærgrupper for Ringen ud over landet - et arbejde, som Sven Hoffmann var blevet koblet på efter sit før omtalte arbejde med at retablere kontakter i Region III i juli 1944. Arbejdsgangen var den, at efter at forbindelsen til nye folk var skabt og aftale om gruppedannelse truffet, blev disse grupper meldt klar hos Jyllandsledelsen, der videregav dem til den respektive regionsledelse. Højland Christensen havde netop skabt en række nye forbindelser i Syd- og Sønderjylland og videregivet dem til Bennike, da Region III blev revet op. Spørgsmålet var, om disse vordende grupper ville gå med i katastrofen, men dette skete heldigvis ikke, og der var hermed et udgangspunkt for endnu en genopbygning af regionen.

Bennikes første forholdsregel i slutningen af oktober 1944 var at flytte grænsen mellem regionerne II og III, således at både Esbjerg og Kolding placeredes under Region II. I forståelse med Bennike til den ene side og sin overordnede $\mathrm{i}$ Ringens arbejde, Højland Christensen, til den anden side var Hoffmann samtidigt gået $\mathbf{i}$ gang med at grave kontakter op i Nordslesvig. I kraft af denne virksomhed var Hoffmann i stand til at fore disse to parter sammen, og efter nogle møder i Vejle blev ledelsen af Region III lagt i hænderne på Højland Christensen. Dette skete ca. 10. november 1944. Regionsgrænsen blev derefter atter flyttet nordpå, idet Højland Christensen bestemt forlangle at råde over byer af en vis størrelse for at kunne gennemfore arbejdet. Kolding, Esbjerg og Varde kom tilbage til Region III, men Fredericia, Vejle og Grindsted blev i Region II.

Det var et gigantisk arbejde, der forestod den nye regionsledelse, der i begyndelsen kun omfattede Højland Christensen og Hoffmann. Ikke alene var grupperne revet op eller hang løsrevne uden forbindelser, men så godt som $100 \%$ var våben og sprængstof konfiskeret af tyskerne. Af den gamle ledelse var kun Merrild Jensen tilbage, og for at gøre vanskelighedernes mâl fuldt måtte en kort periode af misforståelser og forhandlinger overstås, før et derefter gnidningsløst samarbejde kunne komme i stand mellem de to parter. Arbejdet blev grebet således an, at 
Hoffmann skulle tage sig af genopbygningsarbejdet på vestkysten og Merrild Jensen af østkysten. Efterhånden udvidedes regionsstaben. Endnu i november 1944 blev nordmanden Peter Jebsen knyttet til den. Det var ham, der i 1942 var sprunget af toget ved Bolderslev. Han var natten til den 1. oktober blevet nedkastet med faldskærm ved Ålestrup for at blive tilknyttet Iversens regionsledelse som engelsk forbindelsesofficer. Dette havde Iversens arrestation hindret, men nu blev han i stedet knyttet til Højland Christensens ledelse og blev hovedsageligt beskæftiget med fremskaffelse af og instruktion i vâben og sprængstof.

Efter nytâr 1945 accelererede regionsledelsens vækst. Foruden kurérer og sekretærer knyttedes til den som repræsentant for Ringen højskolelærer Johannes Rosendahl og for Dansk Samling civilingeniør Ole Wever, mens Merrild Jensen efter at være såret i Esbjerg afløstes af lektor E. K. Gabrielsen som kommunistisk repræsentant. Endvidere blev højskolelærerne Jens Kruuse og Jørgen Bøgh samt premierløjtnant O. Stephensen tilsluttet staben, mens politimester E. H. Brix, Tønder, attacheredes som leder af det illegale politi $i$ regionen. Alt $i$ alt talte regionsledelse og -stab hen mod krigens slutning ca. 15 mennesker.

Regionsledelsen holdt i begyndelsen til i Kolding, men mátte som følge af tyskernes efterstræbelser flytte, første gang i februar 1945 til Askov, næste gang i april 1945 til Brørup. Det lykkedes aldrig tyskerne at rive denne regionsledelse op, skønt de flere gange var tæt inde på livet af den. Det kan i denne forbindelse bemærkes, at skønt krigens afslutning efterhånden nærmede sig med hastige skridt, blev Gestapos arbejde ikke slækket.

\section{ARBEJDSGANG OG ARBEJDSVILKAR}

Der var nok at tage fat pâ. Byledere skulle udpeges, og nye grupper dannes. Herunder lagde man vægt på en klar opdeling mellem sabotagegrupperne, der under egen ledelse skulle stå direkte under bylederen, og militær- eller ventegrupperne. Instrukser til dette formål blev udarbejdet og udsendt. Endvidere skulle váben og sprængstof tilføres regionen og viderefordeles til bydistrikterne. Der var en aktion $i$ gang for på een gang at få sendt 8 tons våben og sprængstof til regionen med skib og dermed få fjernet alle forsyningsmæssige bekymringer for lang, lang tid. 
Men ulykken ville, at tyskerne fattede nys om sagen og stod på havnen i Kolding, da skibet en dag i begyndelsen af december 1944 lagde til $\mathrm{kaj}^{18}$ I stedet måtte man nøjes med at modtage forsyningerne drypvis. Den første sending ankom til Vejen pr. jernbane den 2. januar 1945, og i den følgende tid kom derefter en række forsendelser til regionen, der dirigerede dem videre til områdets forskellige dele. Forsyningen blev dog aldrig så stor, at den kunne holde trit med væksten i grupper, og ved befrielsen fandtes der kun våben til stort set halvdelen af ventegruppernes folk - en skæbne, som Region III dog kunne dele med de øvrige regioner. ${ }^{19}$

Peter Jebsen har $i$ en beretning beskrevet arbejdsvilkårene således: $>\mathrm{Nu}$ begynte en meget anstrengende tid. Vi var $\mathrm{i}$ aktivitet hver eneste dag. Arbejdet $i$ regionen hadde ligget nere de siste uker, og vi måtte starte praktisk talt på bar bund. Vi manglet overalt ledere og som nevnt var det tomt for sprengstof og våpen. Højland Christensen var et meget heldig valg til stillingen som sjef for regionen. Han var en rettlinjet og dyktig mann, som oftest hadde en heldig hånd med de ting, han tok fatt på. Som yrkesoffiser hadde han begrep om administrasjon og organisasjon. Han var bestemt og hadde evnen til å inspirere sine folk og til å skaffe seg respekt*. Efter de første tre måneders arbejde var regionens styrke oppe på ca. 2000 mand. Umiddelbart før befrielsen var dette tal vokset til ca. 4000.

I genopbygningens første tid koncentrerede Højland Christensen sig om at få organisationen genskabt og lod derfor sabotagearbejdet hvile - iøvrigt til Jyllandsledelsens utilfredshed. Den så gerne så megen aktivitet som muligt. På dette tidspunkt var ethvert håb om et snarligt og pludseligt tysk sammenbrud forsvundet. Man var indstillet på, at kampen skulle føres til den bitre ende, og selv om forlydender om invasion i Danmark til stadighed verserede, var man klar over, at det meget vel kunne ske, at krigsfronten ville bevæge sig op gennem Danmark sydfra. Den første systematiske sabotage blev sat ind af regionsledelsen i december 1944 mod levnedsmiddelforsyningen til Tyskland. For alvor kom der imidlertid gang i sabotagen, da den i februar 1945 satte en stor offensiv ind mod jernbanerne, hvilket kunne gøres så meget lettere, som den danske civile trafik på dette 
tidspunkt var så godt som indstillet. I hele Jylland satte i krigens sidste måneder jernbanesabotagen ind mod tyskernes bestræbelser på at føre så mange tropper som muligt fra Norge ned til de betrængte fronter ved Tysklands grænser $\mathrm{i}$ øst og vest. Hver gang tyskerne havde landsat nye troppeafdelinger $i$ Frederikshavn, Ålborg eller Århus til videre transport pr. jernbane sydpå, satte sabotagen ind med stor effekt. Region III organiserede jernbanesabotagen på den måde, at de forskellige bydistrikter fik tildelt bestemte strækninger af banelinierne, og man blev herved i stand til også at aktivisere grupper, hvis hjemsted lå langt fra banerne.

Ved et lykkeligt tilfældel er en af Peter Jebsens "liaison reports « til London bevaret. Den giver et velkomment glimt ind i samtidens problemer og vanskeligheder. Hans rapport er dateret den 5. april 1945 og meddeler bl. a. følgende i oversættelse fra engelsk:

》Når Gestapo går i aktion, er det sædvanligvis lederne, der rammes. Dette er nu sket så ofte i regionen, at de fleste af vore gode folk er borte, og vi finder det meget vanskeligt at grave nye op. Distriktet er kendt for at være vanskeligt at være $i$, og når folk går under jorden, foretrækker de derfor at forlade regionen, og vi kan ikke friste nogen udefra til at tage deres pladser. Gestapo har kendskab til regionschefens, vestkystrepræsentantens $^{20}$ og min egen eksistens. Trods mange arrestationer, også blandt sabotageledere og deres grupper, har vi kunnet fortsætte sabotagen i samme omfang som før med naturlig koncentration om jernbanesabotagen.

Når transporter ventes, benytter fjenden store styrker til at bevogte jernbanen. Om dagen står de med 50-100 meters mellemrum, om natten har de stået så tæt som med 25-50 meters mellemrum. De har ikke blot vagter på sporene, men har dem også siddende i dækning på begge sider af linien rede til at skyde på vore folk uden varsel.

Jeg har nu givet instruktion i næsten hele regionen, så at de alle kender deres våben og sprængstof. Men træning i terrænbenyttelse, taktik etc. er ikke kommet ret langt. I de bydistrikter, hvor en officer har ledelsen, er der blevet gjort noget arbejde $i$ den henseende, men alt $i$ alt er niveauet meget lavt. Hovedgrun- 
den hertil er manglen på ledere og de gentagne Gestapo-aktioner, der har rystet organisationen. Rekruttering i stor stil kunne gennemføres, hvis der var tilstrækkeligt med våben og ledere ".

\section{ABENRÅS SIDSTE REKONSTRUKTION}

Ligesom i juni/juli 1944 stod man i oktober atter over for det langsommelige og vanskelige arbejde at retablere forbindelserne. Ảbenrå hørte ikke til de Ringen-kontakter, Højland Christensen som tidligere nævnt havde skabt, og man stod derfor oprindeligt helt uden forbindelser til byen. Sven Hoffmann var kort efter Iversens arrestation af en gammel illegal forbindelse fra Haderslev blevet underrettet om det skete og kaldt til Assens. Han tog derfra til Jylland og fik i Sønderborg et møde i stand med Bondo Svane nogle dage før dennes arrestation den 19. oktober 1944. Under samtalen fik Hoffmann oplyst apotekbestyrer Svend Aage Poulsens navn. Da Bondo Svane blev arresteret, fik det ingen følger for Poulsen, og Hoffmann kunne derfor, da han i dagene omkring den 1. november 1944 var i Abenrå, henvende sig til Poulsen for med denne at drøfte problemet om at skaffe en ny byleder til Åbenrå. Flere muligheder blev undersøgt, men først da man henvendte sig til grosserer Kristen Dam Sodborg, lostes problemet, og da Højland Christensen i midten af november 1944 kom til Ảbenrå, indsatte han Dam Sodborg som byleder.

Omkring denne opbyggedes derpå en ny byledelse. Svend Aage Poulsen fungerede i starten som stedfortræder for Dam Sodborg, men afløstes som sådan i det tidlige forår 1945 af dyrlæge Kai Mogensen. Gradvist blev byledelsen udvidet. Løjtnant Peter Larsen blev leder af sabotagefolkene. I februar 1945 ankom kaptajnløjtnant H. H. Quistgaard Bay og kriminalbetjent Ib Holten som militære sagkyndige og våbeninstruktører. Bag kulisserne spillede fru Sigrid Nordemann Jensen en stor organiserende og inspirerende rolle, hvilket hun for øvrigt også havde gjort $i$ de forudgående perioder.

Arbejdet med at stable grupper på benene gik i begyndelsen langsomt og sinkedes af personlige uoverensstemmelser af forskellig art. Således blev de ventegrupper, der allerede $\mathbf{i}$ farver Jacobsens periode var dannet ud fra Sct. Georgsgildet, og som havde overlevet både maj/juni- og oktober-oprivningen i een lang, 
endeløs venten på våben og opgaver, ikke straks tilkoblet den nye - tredie - byledelse. Det skete først på et så sent tidspunkt som begyndelsen af marts 1945 . Også andre gruppedannelser svævede frit i luften uden jordforbindelse. Det gjaldt således grupper blandt Forsvarsbrødrene, der først blev tilsluttet i slutningen af april 1945. Det illegale arbejdsklima var så dårligt, at Højland Christensen selv måtte en tur til Ảbenrå for at få tingene til at glide og samarbejdsånden befordret.

Belastende for arbejdet virkede endvidere forholdet mellem byledelsen og politiet, der siden den 19. september 1944 befandt sig under jorden. Politiet ville ikke uden videre lade sig indrangere $i$ den skabte organisation og lade sig anvende til f.eks. sabotageaktioner, men onskede at bevare sig intakt. Til gengæld blev våben nægtet det, da sådanne begyndte at ankomme til byen. Først umiddelbart før kapitulationen fandt de to parter frem til en modus vivendi, der kunne overvinde den gensidige mistillid og tilføre bydistriktet 50 mand i ni grupper.

Trods disse vanskeligheder, der nødvendigvis virkede hæmmende på arbejdet, kunne Åbenrå bydistrikt ved krigens afslutning stille 240 mand i 40 ventegrupper og et dusin sabotagefolk $i$ to grupper. Disse tal omfatter både grupperne i Ảbenrå by og oplandsgrupper i Hovslund, Genner, Løjt, Hellevad, Nr. Hostrup, Klovtoft, Rødekro, Varnæs, Bovrup, Felsted og Bolderslev.

Våben ankom til Åbenrå bydistrikt i tre omgange. Den første sending, regionen dirigerede til det sydøstlige Nordslesvig, ankom søndag den 4. februar 1945 og oplagredes hos gårdejer Hans Lilholdt, Brunde. Det drejede sig om ca. 2 tons, der skulle viderefordeles ikke blot til Åbenrå, men også til Sønderborg, Gråsten og Padborg. Kun en mindre del af denne beholdning var blevet videredistribueret, da tyskerne $i$ midten af måneden slog ned på depotet. Senere - den 10. marts 1945 - blev gården sprængt som repressalie. I slutningen af marts 1945 ankom en sending - især omfattende sprængstof - i dritler til Søst skov. Endelig ankom $i$ de sidste besættelsesdage $i$ begyndelsen af maj 1945 en større sending, som afhentedes $i$ Broager. Langt om længe var Ảbenrå blevet velforsynet med våben.

Tilførsel af sprængstoffer var forudsætningen for, at sabotagen kunne antage det fornødne omfang. Efterfølgende liste giver 
en oversigt over, hvilke aktioner der udførtes $i$ denne sidste fase. Der må dog gøres et forbehold over for dens korrekthed, for så vidt anyăr jernbanesabotagerne. I krigens sidste tid opererede de forskellige bydistrikter meget tæt på hverandre. Således bestod i april 1945 den ordning, at Haderslev havde fået tildelt strækningen indtil Over Jerstal exclusive (det vil sige stationsterrænet undtaget), Toftlund strækningen Over Jerstal inclusive - Hovslund inclusive, Ảbenrå strækningen Hovslund exclusive - Bolderslev inclusive og Sønderborg strækningen Bolderslev exclusive - Bajstrup inclusive. Der består derfor muligheden af, at aktioner, der tilskrives Åbenrå, har været udfort af nabodistrikterne, ligesom den modsatte mulighed, at Ảbenrå bydistrikts grupper har udført aktioner uden for deres egentlige område, og at disse derfor ikke er medregnet $i$ listen, må tages $i$ betragtning. Fejlkilden er dog formentlig kun ringe.

Dato Aktionens art $\quad \begin{gathered}\text { Afbrydelsens } \\ \text { varighed } \\ \text { i timer }\end{gathered}$

11/12. dec. Togafsporing Hovslund-Over Jerstal i $\mathrm{km} 71,5 \quad 10^{1 / 2}$

15/16. dec. Togafsporing Rødekro-Hovslund i km 73,2 $\ldots . .19$

23/24. dec. Formodet sabotage Hovslund-Over Jerstal .... 4

9/10. feb. Togafsporing Hovslund-Over Jerstal i km 67,7.. $4^{3 / 4}$

4/5. marts Skinnesprængning Rødekro-Hovslund i km 74,91

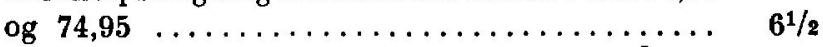

9. marts Sabotage mod to biler og transformator i Abenrå. Aktionens ægthed dubiøs.

19. marts Sabotage mod benzingodsvogn, Abenrå station.

31. marts/

1. april Skinnesprængning Bolderslev-Hjordkær i $\mathrm{km}$

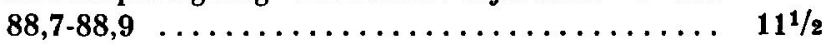

3/4. april Forgæves forsøg på togafsporing.

6/7. april Forgæves forsøg på togafsporing.

10. april Seks cementblandemaskiner odelagt, Åbenrå havn.

13. april Kolevogn og cementblandemaskine odelagt, Åbenrå station.

14/15. april Skinnesprængn. Bolderslev-Hjordkær i km 88,1 $7^{1 / 2}$ 15/16. april Sprængning af lastbil ved Kliplev.

26. april Sprængning af lastbil i Ảbenrå.

I sin ovenfor citerede rapport til London karakteriserer Peter Jebsen arbejdet i Åbenrå således: $E t$ stort våbenlager fundet af Gestapo på grund af dårlig security. Sabotagegrupperne sva- 


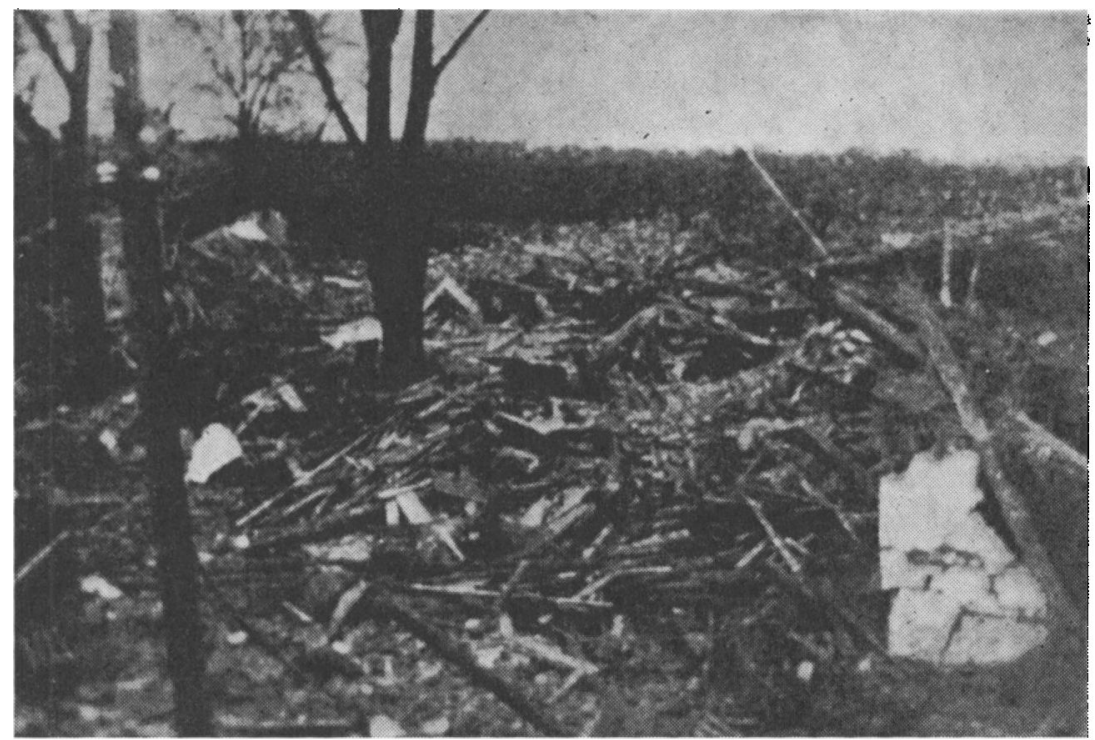

Resterne af Hans Lilholdts gård $i$ Brunde, efter at den som repressalie var sprangt $i$ luften den 10. marts 1945.

gex. Peter Jebsen ønskede ikke at putte blår i øjnene på London, men dette til trods kan hans lakoniske vurdering af bydistriktets sabotageindsats synes vel hård. Den må imidlertid ses på baggrund af den meget energiske og effektive indsats, andre bydistrikter øvede i samme periode - således eksempelvis Rødding, Vejen og Esbjerg. $\mathrm{Og}$ det må tilføjes, at den dårlige security ikke kunne lægges Åbenrå til last.

\section{DEN CIVILE MODSTANDSBEV EGELSE}

Parallelt med den her skildrede opbygning af regionens militære apparat gik en politisk fundering af modstandsbevægelsen. I efteråret 1944 tog Frihedsrådet efter tilskyndelse fra England initiativet til oprettelse af lokalkomiteer over hele landet. De allierede onskede oprettet lokale koordinationsorganer, der kunne gennemføre Frihedsrådets paroler, og som de kunne træde $i$ forbindelse med, når eller hvis fronten bevægede sig gennem Danmark. Lokalkomiteernes arbejdsområde var klart politisk, og 
deres kompetence defineredes af Frihedsrådet således: 'Lokalkomiteerne er først og fremmest tænkt som formidlende organer og alene i lokale spørgsmål. Når forholdene ikke tillader først at indhente forholdsordre, er lokalkomiteen bemyndiget til at optræde selvstændigt i Frihedsrådets navn ".

Det gjaldt om ved oprettelsen af lokalkomiteer at give dem en sådan organisatorisk og politisk bredde, at de var modstandsmæssigt repræsentative - helst skulle alle fire store organisationer være repræsenterede - og iøvrigt være i besiddelse af de rette kontakter til de normale instanser $i$ de respektive byer. Bylederen skulle enten personligt eller gennem en stedfortræder være repræsenteret i lokalkomiteen. Det lader sig ikke nægte, at forholdet mellem modstandsbevægelsens militære instanser og denne nyoprettede politiske instans mange steder var anspændt, fordi kompetencefordelingen ikke var klart defineret, og de to parters initiativtrang og virkelyst derved kolliderede. De fleste steder blev lokalkomiteens væsentligste praktiske funktion den at forberede de lister, efter hvilke interneringer efter befrielsen skulle foretages.

I Nordslesvig oprettedes i nøje overensstemmelse med Frihedsrådet endnu en politisk instans, nemlig Modstandsbevægelsens sønderjyske råd. Det havde til opgave dels at fungere som en landsdelsinstans, de allierede kunne samarbejde med, hvis krigen bevægede sig op gennem Jylland, dels at virke som et politisk udvalg til behandling af specielle sønderjyske efterkrigsproblemer. Dette sidste ville forst og fremmest sige forberedelsen af opgøret med det tyske mindretal. Det blev da også i denne sidste funktion rådet fik betydning. Ved udpegningen af rådets fire medlemmer lå to synspunkter til grund. Dels onskede man også her de store modstandsorganisationer repræsenteret, dels ville man koordinere dette med en geografisk repræsentation. Forholdet mellem Det sønderjyske Råd og regionsledelsen var ikke harmonisk. Højland Christensen og Jens Kruuse deltog $i$ et par af rådets møder, men parterne nåede ikke til enighed i spørgsmål om kompetence, repræsentativitet og målsætning.

For Ảbenrås vedkommende blev såvel lokalkomite som Det sønderjyske Råd aktuelle begreber, da ungdomskonsulent Tage Albertsen den 17. november 1944 kom på illegalt besøg i byen. 
På et møde hos Dam Sodborg konstitueredes en lokalkomite for Ảbenrå. Den kom til at bestå af Svend Aage Poulsen som repræsentant for Ringen, slagteridirektør Frederik Johansen og gårdejer Mads Lilholdt, Fasbro, som repræsentanter for Dansk Samling og Dam Sodborg som repræsentant for den militære modstandsbevægelse. Hertil kom senere guldsmed C. C. Rode som repræsentant for Frit Danmark. Poulsen blev komiteens formand. Dens sammensætning viser klart, at der på dette stadium af arbejdet ikke fandtes nogen kommunister i byen, ligesom der heller ikke var nogen egentlig Frit Danmark-gruppe. I Ȧbenrå som andetsteds blev det komiteens vigtigste opgave at forberede interneringslister, og kurérer kom rejsende udefra for at give den fornødne vejledning heri.

Ved Tage Albertsens besøg drøftedes også oprettelsen af Det sønderjyske Råd, og Svend Aage Poulsen indtrådte heri som repræsentant for Ringen og for Åbenrå.

\section{KAPITULATION OG BEFRIELSE}

I foråret 1945 blev det klart, at krigen nærmede sig sin afslutning, og muligheden for, at de allierede ville rykke frem gennem Nordtyskland og Slesvig-Holsten videre mod nord, blev stadig mere aktuel. Region III kom derved til at indtage en central placering. Tyskerne var allerede forlængst begyndt at forberede interimistiske forsvarsanlæg tværs gennem Nordslesvig, ${ }^{21}$ og kamphandlinger i området kunne forventes. I England udarbejdede man planer for nedkastningen i Danmark af tremandsgrupper bestående af en allieret officer, en danskfødt allieret officer og en telegrafist til taktisk støtte af regionerne. Udløsningen af disse grupper nåede imidlertid ikke at blive aktuel, for krigen bragtes til en hurtig og for Danmarks vedkommende fredelig afslutning.

Endnu til det sidste måtte man dog $\mathrm{i}$ regionsledelsen regne med muligheden af, at det ville komme til kamphandlinger på dansk område. Ganske vist havde den svenske radio den 1. maj meddelt, at tyskerne kapitulerede, men den forhastede glæde måtte atter vige for realiteterne, da meddelelserne viste sig at være falske. Til at tage vare på alle eventualiteter sendte Højland Christensen i krigens sidste dage Jens Kruuse og O. Stephensen til grænseområdet som "grænsekommando *. Deres opgave var 
at træde $\mathbf{i}$ forbindelse med englænderne, hvis disse trængte kæmpende frem, at etablere en grænsespærring, hvis krigen standsede uden for Danmarks grænser, i det hele taget at improvisere sig frem gennem de muligheder og vilkår, der bød sig. Således søgte Jens Kruuse i de sidste dage af april kontakt til grev Folke Bernadotte, der på dette tidspunkt på Brøndlund slot førte forhandlinger med SS-officeren Walther Schellenberg, men nåede ikke igennem til ham. Efter at meddelelsen om den tyske kapitulation var kommet fredag den 4. maj om aftenen, etablerede de fra næste dags morgen en grænsespærring til og fra Tyskland. ${ }^{2}$ Ved hjælp af ca. 800 mand fra den åbnede Frøslev-lejr og ca. 1700 mand fra regionens forskellige bydistrikter oprettedes en bevogtningstjeneste af grænsen i fredens første par uger.

Som de fleste andre steder forløb også i Åbenrå overgangen til freden uden større komplikationer. Ganske vist indtog den lokale tyske kommandant, major Geyer, endnu om morgenen den 5. maj en krigerisk holdning, og byledelsen måtte kl. 10,20 meddele til regionsledelsen: "Den tyske kommandant vil ikke forhandle. Truer med at beskyde danske poster ved en benzintank og $\mathrm{i}$ det hele taget alle bevæbnede danske frihedskæmpere på gaden . Men efter forhandlinger mellem Geyer, borgmester Holger Fink, H. H. Bay og Dam Sodborg lykkedes det dog at nå til en $\gg$ Overenskomst af 5 . maj $1945 \mathrm{kl}$. $11 \mathrm{om}$ afgrænsning af de politimæssige beføjelser mellem $*$ Wehrmacht-Standortältesten", borgmesteren og lederen af modstandsbevægelsen i Ảbenrå «, ved hvilken værnemagten anerkendte modstandsbevægelsens politimæssige kompetence, herunder dens ret til at foretage interneringer.

Uden mislyd blev befrielsesdagene dog ikke. Den var af intern dansk karakter og en sidste udløber af det gamle modsætningsforhold mellem de traditionelle nationale førere $i$ landsdelen og de modstandsaktivistiske kredse. I fuld overensstemmelse med regionsledelsen og i lighed med, hvad grænsekommandoen havde gennemført ved Kruså, forhindrede byledelsen i Abenrå, at amtmand Refslund Thomsen deltog $i$ modtagelsen af de første englændere i Åbenrå mandag den 7. maj. Dette skabte naturligvis misstemning, og denne misstemning rettede sig mod bylederen, Dam Sodborg. ${ }^{23}$ Det var to vidt forskellige verdener, der i skik- 
kelse af amtmanden og bylederen tørnede sammen, og modsætningen mellem dem skal ikke tilsløres, men konstateres som en kendsgerning. Dette er iøvrigt et forhold, der har gyldighed ikke blot for Åbenrå, men for hele landsdelen. I et møde i Dansk Samråd, der siden 1940 regnede sig for den sønderjyske danskheds kompetente organ, kunne redaktør A. Svensson i marts 1945 som svar på en udtalelse om, at det ikke var for tidligt at få forbindelse med modstandsbevægelsen, således sige: "Så måtte vi jo vide, hvor modstandsbevægelsens repræsentanter er at finde . Replikken afslører den fuldstændige mangel på kommunikation - bogstaveligt og åndeligt - mellem de to parter. ${ }^{24}$

\section{AFSLUTTENDE BEMÆRKNINGER}

I visse henseender rummer Åbenrås illegale historie specielle træk. Det er således bemærkelsesværdigt, at byen var hjemsted for den første regionsledelse i området, hvilket var en konsekvens af Åbenrå-kredsens eksistens. Endvidere falder det $i$ øjnene, at kommunisterne spiller en meget ringe illegal rolle. I den tidlige periode og $\mathrm{i}$ den sidste fase spillede de ingen rolle, ja, de kan overhovedet knapt nok påvises. Kun i tiden fra juni til oktober 1944 førte de sig frem, og for denne periodes vedkommende synes der at være tale om konvertitter af næsten samtidig dato. ${ }^{25}$ Sammenligner man med andre nordslesvigske byer - for slet ikke at tale om kongerigske -, er det kommunistiske indslag i den illegale bevægelse langt kraftigere andetsteds end i Abenrå. At byen ingen Frit Danmark-gruppe havde, har den fælles med mange andre byer.

I andre henseender er Abenrå illegalt set ganske normal. Den delte med regionens øvrige byer de store tab, som modstandsbevægelsen led som følge af tyskernes oprulninger af organisationen. Her som ofte andetsteds i regionen var den illegale "levetid " ganske kort, i mange tilfælde blot $2-3$ måneder. Ligeledes indgik byen på fuldstændig lige fod med andre byer $\mathrm{i}$ de reorganiseringsbestræbelser, der fulgte $\mathrm{i}$ kølvandet på hver oprulning. Den samme ensartethed gælder rekrutteringen. Ligesom det $i$ by efter by hele landet over var nye $-i$ politisk henseende hidtil betydningsløse eller uprøvede - kræfter, der tog initiativet og bar det illegale arbejde frem, således var det også tilfældet $\mathbf{i}$ 
Nordslesvig og i Åbenrå. De i denne skildring anførte navne på ledere antyder klart forholdet. Til en vis grad er årsagen at finde i generationsforskellen: Det var - også på lederplanet - de unge, der førte modstanden frem. Men dette er langtfra den eneste - eller væsentligste - forklaring. I Nordslesvig blev modsætningen til de traditionelt ledende kredse måske endda skarpere end andetsteds, fordi der til de øvrige eksisterende divergenser i politisk henseende også kom brudflader på det nationalpolitiske område, således i synet på det tyske mindretals stilling efter befrielsen. ${ }^{20}$ Modsætningen blev ikke mildnet gennem tiden, skønt modstandsbevægelsen gradvist fik storre politisk bredde. Det samarbejde, der i krigens sidste tid etableredes i København mellem Frihedsråd og politikere, fandt ikke sin pendant i Nordslesvig.

\section{NOTER}

Skildringen bygger først og fremmest på det kildemateriale, jeg har indsamlet, dels i form af beretninger, der er udarbejdet af modstandsfolk selv, dels i form af referater af samtaler, jeg har f $\varnothing \mathrm{rt}$ med modstandsfolk om deres illegale arbejde. Dette materiale befinder sig i min besiddelse og vil efter endt brug blive afleveret til Rigsarkivet. Da det ikke i øjeblikket er tilgængeligt, er der ikke i noterne henvist til det. For Åbenrås vedkommende drejer det sig om ca. 40 beretninger og samtalereferater.

Ved siden heraf kan nævnes Region III's arkiv, der befinder sig på Landsarkivet i Åbenrå. Det rummer dog f $\emptyset$ rst og fremmest efterkrigsstof. For den almene baggrund henvises til dr. Jørgen Hæstrup, Kontakt med England, 1954, og Hemmelig Alliance, 1959. Specielt for Region III henvises til Johannes Rosendahl, Det kæmpende Sønderjylland i Chr. Demuth (red.), 25 år under Dannebrog, 1947.

1. Til en vis grad danner Det unge Grænseværn/Dansk-Nordisk Ungdomsforbund en undtagelse fra de $\varnothing$ vrige nationale foreninger. Jvfr. iøvrigt Troels Finks vurdering i Sønderjylland siden genforeningen i 1920 , 1955 , s. 140 .

2. Jvfr. Ingeborg Refslund Thomsen: Hjemme i Nordslesvig, 1961, s. 125: $\rightarrow$ Hjemme sagde min mand ofte: $>J e g$ f $\varnothing l e r$ mig som garant for den myndighed, der har betroet mig embedet, hvis det går imod min overbevisning, må jeg træde tilbage, dobbeltspil kan jeg ikke spille!««. Og sammesteds s. 126: *Min mand mente, det kunne ikke vare vor opgave at volde regeringen vanskeligheder ....

3. Jvfr. Hans Mørup: Grænselandet i modstandskamp i Chr. Refslund (red.) : Liv og virke i vort grænseland, 1961, s. $105 \mathrm{ff}$.

4. I Vort Værn, 5/9 1941, skildrer terrænsportslederen J med tilsløring af initiativ og bagmænd arbejdets udvikling.

5. Jvfr. Vilhelm la Cour: For dansk domstol under besættelsen, 1945, s. $67 \mathrm{ff}$.

6. Nyt fra Dansk Samling, 1/4 1943. 
7. Også denne gruppe havde en terrænsportstid, se Vort Værn, 1/3 1941. Der hentydes anonymt til gruppen i Hastrup: Kontakt med England s. $260 \mathrm{f}$.

8. Sabotagen beskrevet i: Åbenrå-Samfundet 1945 , s. 25 f.

9. M. h.t. en vurdering af folkestrejkerne henviser jeg til min kronik $i$ Aarhuus Stiftstidende, 18/8 1963.

10. Om gruppen i Røllum se: Knud. Et mindeskrift om .... Knud Valdemar Andersen, 1945.

11. Sabotagen er bl. a. omtalt i Folkets Røst, 22/6 1945 (interview med Viggo Hansen) og Pigtråd, december 1962 (interview med Holger Danske-manden Jørgen Kieler).

12. Den parlamentariske Kommission, VII, s. 207.

13. Sammesteds, XIV, aktstykker, s. 573.

14. Sammesteds, VII, aktstykker, s. 1889.

15. Om Svane se Beretning om ... Erik Bondo Svanes illegale arbejde, fangenskab og død under tysk tvangsarbejde, 1946.

16. Buschardt, Fabritius \& Tønnesen: Besættelsestidens illegale blade og bøger 1940-45, udg. af Det kongelige Bibliotek, 1954, s. 46.

17. Oversigten er baseret på materiale fra Generaldirektoratet for Danmarks Statsbaner og fra DSB.s 2. distrikt, Århus.

18. Episoden er omtalt i Toldstrup, Uden kamp - ingen sejr, 1948, s. 145.

19. Materielsituationen fremgår af en styrke- og våbenliste over $M$-grupperne fra marts/april 1945, aftrykt i Hæstrup m. fl.: Kilder til modstandsbevægelsens historie, 1962, s. $162 \mathrm{f}$. - Styrketallene er i $\phi v$ rigt meget usikre; således anf $\varnothing$ res for Region III en styrke på 2400 for medio januar 1945 og på 1550 for medio marts, uden at tyske oprulninger retfærdigg $\varnothing \mathbf{r}$ en sådan nedgang. Tallene findes hos Hæstrup: Hemmelig alliance, II, s. $114 \mathrm{f}$.

20. Sven Hoffmann.

21. Den parlamentariske Kommission, XIV, s. 142.

22. Se Franz von Jessens skildring i C. J. Bech m. fl. (red.) : Befrielsesdage i S $\varnothing$ nderjylland, 1946, s. $78 \mathrm{ff}$.

23. Ingeborg Refslund Thomsen: Hjemme i Nordslesvig, 1961, s. 127; $138 \mathrm{f}$. Smlgn. Jens Kruuse i Jyllands-Posten, 24/11 1961, og Ingeborg Refslund Thomsens svar sammesteds, 27/11 1961.

24. A. Svensson: Dansk Samråd, i Sønderjyske Arbøger 1951, s. 96.

25. Således nævnes i Førermeddelelser, oktober 1945, Egon Nørgaard blandt de KFUM-spejdere, der døde i frihedskampen, men hans illegale engagement var kommunistisk, jvf. laserbrev af Christian Frahm i Information 25/5 1964.

26. Se f. eks. Kai Edv. Larsen: Udviklingen i Nordslesvig i 40'erne, i Nordslesvig efter Genforeningen, 1951, s. 55 f. 